大阪大学医学部, 第 1 解剖学教寀 (主任：高木教授).

Ist Dept. of Anat., Med. School of Osaka Univ. (Director: Prof. K. TAKAGI).

\title{
星細胞と朋細胞との関係.
}

\section{Relation between KUPFFER and Liver Cells.}

\section{石橋 悟 Satoru ISHIBASHI.}

〔昭和 29 年 5 月 9 日原稿受付〕

\begin{tabular}{|c|c|c|c|c|}
\hline & 目 & 次 & & \\
\hline & 実験 & $\begin{array}{ll}\cdots & \cdots\end{array}$ & ... & 525 \\
\hline & 注射実験... & $\begin{array}{llll}\ldots & \ldots & \ldots\end{array}$ & $\cdots$ & 53 \\
\hline & 圭射実験… & $\begin{array}{ll}\cdots & \cdots\end{array}$ & $\cdots$ & ․ 535 \\
\hline & ててのゼラチ & 験 & $\cdots$ & \\
\hline & 昉酸の胵 & & $\cdots$ & \\
\hline
\end{tabular}

\section{篇 1. 星細胞閉塞實驗.}

星細胞と肝細胞との相互関係と就ては種々論議されているが，今な招推 量の域を脱しない点がすくなくない。之は星細胞自体の機能が未だ明かで ないことに原因する処が大きい。抑々，星細胞機能の研究にあたっては， Aschoff (1924), Eppinger（1923）等飞依り提唱せられた閉塞実験, 清野 氏（1914）等飞依る生体染色が従来用いられているが，之だけでは星細胞 の機能を僐細に把握するとは充分とは言い難く, 須らくこれと平行して肝 細胞を咩細に観察すべきである。本教室と於ては数年前より肝細胞機能を 細胞微細構造の面から研究せられ，種々なる条件下に於ける肝細胞機能， 特に物質代謝に関し多数の報告がなされた。茲に於て余は之等の知見を基 礎に招き，閉塞実験を試みたのが本研究である。即ち星細胞を閉寒と依り 一時その機能を抑制せしめた際，肝細胞機能が如何なる影響をうけるかを 明かとし，以て星細胞と肝細胞との関係を闈明とせんことを期した。而し てかくすることは星細胞機能を明か、する所以であると信ずる。之が本研 究の目的である.

\section{I. 研究材料と方法.}

第 1 実験. 24時間空腹に保てるラッテを2群に分け，I 群には墨汁 $2 \mathrm{cc}$ 腹腔内飞注射した後， $10 ， 30$ 分，1，3，6，12，18，24及び 48 時間をへて取 材して時間的差異を求め, II 群には墨汁 $0.5 ， 1 ， 2 ， 3 \mathrm{cc}$ を注射し，すべて 3 時間後に取材して墨汁量による差異を追及した。即ち第 1 実験より得た 所見はすべて空腹時，換言すれば肝細胞機能の静止期飞於けるるのである. 
第 2 実験。24時間空腹ラッテを 2 群飞分け，I 群には墨汁 $2 \mathrm{cc}$ を腹院内 に注射し， 3 時間をへた時，所定の食餌（即ち 3 栄養素及び各種ビタミン， 塩類をもって調製したもの）を与光，それより $1 ， 3 ， 6$ 時間後に取材し， II 群飞は給食と同時飞墨汁を汴射し，前同様 1，3，6時間をへて取材，以 て星細胞の閉塞と肝細胞構造の食後の動きとの関係をみることを主眼とし た.すべて取材はエーテル麻酔下と行い，固定飞は Formol 液. Carnoy氏 液, Levi 氏液, Zenker 氏液, 染色飞は Scharlachrot 染色, Best 氏 Carmin 染色, Heidenhain 氏鉄へマトキンリン染色及びピロニン染色を用いた。

\section{II. 所見と考察.}

\section{A. 第 1 害驗 (空腹時所見).}

1. 墨粒. 墨汁 $2 \mathrm{cc}$ 注射後10分にして既飞肝小葉周辺部の星細胞飞極め て僅少の墨粒が認められる。爾後, 墨粒を搔取した細胞は増数し，3時間 後には小葉全域に及ぶ。他面飞は細胞中の墨粒も増量し，6時間になると 肥大せる胞体を充満し，星細胞は恰も墨粒塊の如く見える（図 1 ）。它く て12時間後では，小葉中心部飞於て墨粒減少の傾向を示すが，周辺部並飞 中間部にあっては 2 昼夜後飞も依然として多量を認める. 以上は墨粒出現 の大要であるが，一方には墨粘を殆ど揁取しない星細胞のあることは注目 に価する．次に墨汁量を変えて注射したII群では，掑取する細胞の数及び 摂取量は注射量飞略々比例することが明かて認められる。即ち，0.5cc， 1ce では細胞数が少ない許りでなく, 周辺部の星細胞と雖も胞体が墨粒で 充満するが如き事はないが，2cc では前述の如く多数の星細胞が多量の墨 粒を椇取し，3cc になると更飞著しい，以上の所見より墨汁を注射すると， 6 時間後には大多数の星細胞が多量の墨粒を撕取し, 星細胞閉寨の目的は 此の時概ね達し得たと思われる，次に肝細胞飞於ても，12時間をすぎると 小葉周辺部より中間部にかけて少数の細胞飞墨粒をとっているのがみられ るが，その後の動きは著明でない．亦 2 日迄の観察では胆管内に全く墨粒 を認めなかった。

2. 糖原。各例とも星細胞は勿論肝細胞飞も全く認めない. 之は非閉塞, 即ち対照と同様である。

3. 脂肪．各例を通じて，少数の星細胞飞僅少の脂肪粒をみるが，之等 は殆ど時間的消長を示さない，他方肝細胞にも，小葉周辺部に中等量の脂 肪粒を抢有するものあるが，之らは概ね小粒子で脂肪滴に迄は発達しない。 而して星細胞飞墨粒が多量飞現われる時期には，一時的飞せよ肝細胞に脂 肪が多少増量するかにみえるが，18時間以後では明かに減少し，2昼夜後 
には僅少の紐胞が若干の脂肪粒をもつとすぎない.

4. RNA. 星細胞のピロニン好性物質は淡く紅染するのみで，墨粘摂 取に応じて見学難くなる，之に反し朋細胞にては注射後 3 時間，即ち星細 胞に於ける墨粒の出現著明となる時期に至れば RNA は著明に証明せられ， 空腹時なるに拘らず，大形塊状となって細胞周辺部に存在するか，或は時 そ依り濃染せる網状を呈して胞体全面飞認められる。 かくて12時間後では 小形塊状をなして均等分布を示し，48時間にて空腹時と同じ様になる.

5. ミトコンドリア．元来星細胞と於けるミトは繊細な桿状乃至糸状を 呈し数も一般飞少ない，然るに墨汁 2cc を注射した場合には，10分後より 墨粒の出現と相俟って小顆粒状多くなり，3 時間後では短桿状, 亜鈴状が みられ，24時間後とは再び顆粒状が多く，48時間では糸状，桿状の静止型 そかえる. 勿論, 墨粒が胞体飞充満する細胞にあってはミトを確かめる事 は困難である。一方肝細胞では，星細胞よりも稍々遅く，注射後 1 時間よ り 6 時間に亘りミトに多少の肥大を認めるが (図 2), その後再び空腹時 所見にもどり，48時間後, 即ち給食後72時間に至ると一部肝細胞ミトは著 明飞減少し, 又染色性も低下し且つ肥満顆粒状となるのが認められる。次 飞墨汁量を変光た場合飞は，3時間後にて星細胞ミトは注射量飞依て夫夕 異った形態を示し， $0.5 \mathrm{cc}$ では顆粒状が多く，1cc では短桿状，顆粒状が 主体をなし，3cc では短桿状を旺する，然ると肝細胞では， $0.5 \mathrm{cc}$ 注射で は何等の変化を招来せず, $1 \mathrm{cc}$ 以上を用いた時にミトの肥大が認められた が，著明な形態変化はない。

小括．以上の所見を要約すれば，星細胞の墨粓摂取は，腹腔内注射後10 分にて既飞小葉䦙辺部飞於て起り，時間の経過と共飞中心部に波及し， 6 時間にてその極に達する。 かくて24時間以降になると中心部にては墨粒の 消失がみられるが，中間部及び周辺部では大差がない，この事は，Kupffer （1899）が家兔で24時間後にみた所見と一致する。な招墨粒㠌取細胞の数 及び摂取量は略々注射量に比例する 而して星細胞と於ける墨粒摂取の開 始と殆ど時を同じうしてミトは顆粒化し，墨粒消失の頃となると再び糸状 乃至桿状の静止型となる. 然しこの動きのみではミトが墨粒摂取に如何程 の役割を演じているかは判然しない, 次に肝細胞飞於ては, 星細胞閉塞飞 依る影響をうける事は否めない。即ち星細胞に墨粒の出現するより遅れて ミトは肥大し，また小葉周辺部の細胞飞於ては筀腹時なるとも拘らず，一 時的飞脂肪が増量してくる事は注目に価する。 


\section{B. 第 2 實驗（給食時所見）.}

1. 墨粒. 墨汁注射後 3 時間を経て人丁.食を投与しても（I群）また墨 汁注射と同時飞給食しても(II 群), 星細胞の墨粒摂取は前項の空腹時所 見と大差がない。

2. 糖原。星細胞糖原は，I群飞あっては給食後 6 時間で漸やく若干の 細胞飞少数の糖原顆粒が出現する。然るとII群では給食後 3 時間に於て既 に小葉中間部周辺部の一部星細胞に小粒子として現われるが， 6 時間後に なると全く消失する，即ち星細胞が墨粒を充分搷取したと思劣る時に給食 した場合よりも，給食後直ちと墨汁を注射した時の方が早く星細胞飞糖原 が証明される。乙の時墨粒の有無は関係がないようである。次に肝細胞で は，I群とあっては給食後 1 時間で周辺部に少量の糖原をみるが（罒 3 ）, 6 時間後になると小葉全般に亘って出現する。但し糖原量としては少量の 範囲を出でない，之に反しII群では 1 時間で既飞前群より稍々多くの糖原 が周辺部に現われ，3時間後には更に増量して小葉全般に亘り中等量に達 するが (図 4).6 時間後には早くも殆ど認めぬ程度飞減少する. 即ち肝細 胞とあっては星細胞がもと墨粒を摄取している時は，給食しても糖原の出 現が少なく，墨汁注射と同時飞給食した時には遙か、多い，然し闭群を通 じて非閉寒, 即ち対照群飞比して肝糖原の出現が低調である事は否めない. このことは星細胞閉寒時飞蔺萄糖を注射しても, 朋糖原は少量しか現われ ないという山形（1952）の報告と一致する。

3. 脂肪. 星細胞飞ては, I 群飞於て給食 1 時間後飞少量の脂肪粒を有 する細胞が全般に亘って散在するにすぎないが， 3 時間後には明かに増数 する，但し個々の脂肪粒は微小で且つ少量であることに変りがない，かく て 6 時間後飞於ても之と大差を認めないが，墨粒と同時に脂肪粒を有する るのもかなりある。II群と於ては，1時間で小葉各部反少星乃至中等量の 脂肪粒をとっている細胞が散在する，爾後の増量は著明でなく，脂肪粒が 胞体を充満するが如きはみられない，また肝細胞では，I 群と於て 3 時間 後に始めて微小な脂肪精を有する細胞が小葉周辺部に少数出現し，6時間 後に至っても增量は著明でない，II 群では 1 時間後に既に脂肪粒を有する ものが，小葉周辺部より中間部以亘ってみられ，3 時間後では中等大の脂 肪粒も散見するが, 前例飞比して増量するとは言い難く, また 6 時間後も 大同小異である。之を要すると本赛験に於ては星細胞, 肝細胞を問はず脂 肪の消長は極めて低調で，その出現は非閉寒の対照に比して遙かに少量で ある，而して星細胞とあっては墨粒に依て閉塞されているから，この事実 
は当然のことと考光得るが，肝細胞に於ける脂肪出現の低調は単なる星細 胞閉塞のみをもって説明することは困難で，星細胞の機能低下が肝細胞脂 質代謝飞影響を与へているものと考究ざるを得ない。

4. RNA. 星細胞飞あっては前項空腹時所見と大差を認めない. 然るに 肝細胞 RNA は，1群の給食 1 時間後では均等性で且つびまん性と分布す るものが多いが，3 時間になると㤥の周囲に染色展の高い小塊状を示する の及び網状を呈するものをみ，6時間後には網状が多い，II 群では 1 時間 後にはび末儿性分布が多いが，3時間になるとこの他に網状を呈するもの が現われ，6時間後も同様である. 斯の如く阿群飞於ける在異は判然しな い.

5. ミト，星細胞ミトは，I群 1 時間後では顆精状を呈するものが多い が， 3 時間後では之と短桿状を混ずる。6 時間後も大差ない.II群でも給 食後のミトは之と大同小異である。他面肝細胞では，I群とあっては 1 時 間後連珠状，亜鈴状に顆粓及び短桿状を混じている，3時間になると桿状 の増加をみる（図 5 ). 6 時間では空胞の出現に応じてミトは聚落を形成し， また顆粒状より桿状に至る各種の形態を呈する。II群では 1 時間後顆粒状 を主とし，之に連珠状，桿状を混じているが，3時間では糖原による空胞 多く現われ, 且つ融合する為, ミトの聚落形成が著明であり, また連珠状 より顆粒.状迄各種の形態を示す（罒 6 )。6 時間になるとミトは稍々繊細 で桿状が增加する。

小括. 以上の所兒の如く, 星細胞を閉寒してから給食すれば, 肝細胞の 物質代謝は正常とかなり異なるよう飞思われる。即ち糖原の出現は低調で， ことに墨汁を予め注射した後給食すれば， 6 時間後に漸やく出現する。之 そ反し墨汁注射と同時に給食した時には，前群より早く現われるが非閉塞 よりも少なく，また前例よりも早く6 時間後には全く消失する。このほか 肝細胞飞於ける脂肪の消長も極めて低調である. 之を供付ける如く肝細胞 ミトは，給食後間もなく動的形態を呈するも，間もなく静的にもどる，斯 る所見より星細胞機能低下時にめっては, 肝細胞機能も亦低調であると言 うことが出来, 星細胞と肝細胞の間飞密接な機能的相関々係の存在するこ とが觉觉える。

\section{III. 結 語.}

墨汁を腹腔内飞注射して星細胞を閉塞したラッテの空腹時及び給食時飞 於ける星細胞並飞肝細胞構造の機能的動態を検討し次の如き所見を得た.

1. 墨粒は注射後10分で小葉周辺部の星細胞に少量現われ，3時間で中 
心部迄ひろがると同時に量も多くなり，6時間前後にてその極飞達する： かくて12時間をすぎ18時間後では中心部て於て減少を始めるが，中間部及 び周辺部では 48 時間後でもまだ減少の傾向を示さない，斯る墨粒の消長は 空腹時たると給食時たるとを問わない。

2. 糖原は空腹時には殆ど出現せず，給食と依り初めて肝細胞飞現われ るが, 非閉塞, 即ち対照飞比して著しく低調である. 殊飞予め閉塞して後 給食したものに於ては，閉塞と同時に給食したものに比し更と低調である. これによって閉塞に由来する星細胞の機能低下が，肝細胞に於ける糖原形 成浙制的影響を与えているととが考光られる。

3. 脂肪は星細胞飞於て各例飞少量認めると過ざない。この脂肪は給食 しても著明な增加を示さないが，空腹時にも全く消失することはない，之 そ反し肝細胞飞於て一時的に増量し, 後消長する。特に給食赛験飞於ては, 予め閉塞して給食する。また閉塞と同時飞給食したもの何れの場合飞も肝 脂質は食後增加し，のち減少するが，この消長は非閉塞の対照例に比較す ると著しく低調である。この事は星胞細が肝細胞脂質代謝に干与する事を 如実に示している。

4. 肝細胞 RNA は星細胞飞墨粒が多量摄取せられる時期に濃染し増量 が筧光る。

5. 星細胞ミトは墨粒出現に先立って多少の形態恋化を起すが，墨粒が 増大すると従って静止型飞帰える。肝細胞ミトは空腹時には多少の肥大を 認め, 之は拓とらくは閉塞飞基因するものと思われる。之給食すると動 的変化を呈するも，非閉塞に比すれば低調である。

以上の諸事実より星細胞閉塞の結果が，肝細胞にかなりの影響を与える ことが明かである。特飞食後肝細胞飞出現する糖原, 脂肪は星細胞閉塞飞 依て著しく少くなることから，星細胞機能が肝細胞の物質代謝と干与して いる事が細胞形態学の上からも明かである。

\section{篇 2. 肪肪腹腔內注射實驗.}

余は前篇で，星細胞が肝細胞脂質及び糖代謝と干与することを，閉塞実 験を用いて細胞形態学の立場から証明した。然しこの成績を以って直ちに 星細胞は肝細胞への脂質移入の門戸なりと言う Jaffé (1925) や Versé (1925)，その他多くの病理学者の説飞賛成しがたい，こ」に於て余は方向 をかえ，星細胞及び肝細胞の脂肪摂取が，脂肪の種類と関係するか否かの 問題を咒明せんことを期し，本契験を企てた。余はこの目的と向って不飽 
和脂肪酸，飽和脂肪酸，並飞複合脂質を選び，之をラッテに与えて，星細 胞並飞肝細胞飞和ける脂肪摄取機能を形態学的飞追及し，この面から星細 胞と肝細胞つ相関々係を明かにせんとした。 而して投与脂質をかく決定し た所以は，肝蔵飞於て飽和脂肪酸が不飽和化され，代謝されると云う事が 一般に認められているが，これをどこ迄細胞形態学から追及できるか、興 味をもったからである.

\section{I. 研究材料と方法}

実験動物として体重 $100 \mathrm{~g}$ の成熟雄ラッテを用い，之を24時間絶食した 後, 次の如き脂質を $2 \mathrm{cc}$ 腹腔内飞注射した後， $10 ， 30,60$ 分， 3 及び 6 時 間を経て肝の一定部位より取材した。即ち不飽和脂肪酸としてはオレイン 酸, 飽和脂肪酸としては，低級ではあるが吸收率が前者飞匹敵するといは れるラウリン酸，複合脂質としてはレチチン及びヤノールを選んだ．尚脂 肪酸及びレチチンは10\%の割合飞生理的食塩水飞混じたもの，ヤノールは 市販のものを使用した。固定には，Formol 液，Ciaccio 氏液，Carnoy 氏液， Levi 氏液を，また脂肪の検索には，Scharlachrot 及び Sudanblack 染色， Lipoid そ対しては特に Ciaccio 氏法飞依る Lipoid 染色, 糖原検出には Best 氏Carmin 染色，ミトの検索には Heidenhain 氏鉄 Hx 染色を用いた。

\section{II. 所見と考察}

\section{A. 不飽和脂肪酸（オレイン酸）注射.}

1. 脂肪. 星細胞は注射後10分で既にかなりの脂肪粒を有し， 6 時間後 飞至るも減少しない。他方肝細胞にも，10分後は主として小葉周辺部に脂 肪粒をみ，30分後では中間部に，而して1時閒後では小葉全層に及ぶ。之 等脂肪粒は食䭒投与後飞みられるものより微小で，且つ血管側飞配列して いる事が注目される．其の後多少の減少を示すが，6時間後に於ても尚小 葉周辺部より中間部にかけてはかなり多量飞証明され，脂肪粒も増大して いる(図 7 ).

2. Lpoid (Ciaccio 陽性物質)。星細胞では 3 時間以後に至って始めて 小葉周辺部に少量の Lipoid 顆粒が現われるとすぎない，肝細胞に於ても また 3 時間後に漸やく小葉周辺部細胞飞少量現われるが, 爾後増量の傾问 を示し， 6 時間後では中間部細胞にもかなり多く出現している.

3. 糖原。星細胞，肝細胞飞みない。

.4ミト．各時間を通じて星細胞では顆粒状の活動型が多いが，朋細胞 では10分より30分飞亘って顆粒，連珠状が多く，1時間後には短桿状が増 
加し，その後は桿状型が大部分を占める（図 8).

\section{B. 飽和脂肪酸 (ラウリン酸) 注射.}

1. 脂肪。星細胞飞於ける脂肪の出現状態は前例と大差がない，之と反 し肝細胞では，1時間後迄はオレイン酸にみたと同様に現われるが，その 後の減少がかなり著明で，まもなく散在性となる（眓 9 ).

2. Lpoid (Ciaccio 陽性物質). 星細胞では殆ど認めない. 之に反し肝 細胞では早期飞少量現われるが，3時間後となると全く消失している.

3. 糖原。星細胞, 肝細胞飞みない。

4. ミト，星細胞のミトは前者と同じく活動型を呈する．之と対し肝細 胞では， 1 時間迄は前者と大差ないが，3時間後と於ても顆粒，連珠状が 多小（罒10）.

小括. 以上の脂肪酸注射の所見を要約すると, 星細胞にあっては飽和, 不飽和を問わず，脂肪酸注射後まもなく脂肪が現われ，6 時間後飞も尚減 少しない。またLpoidは不飽和脂肪酸注射後少量現われるが，飽和脂肪酸 では全く出現しない。ミトは長時間に亘り活動型を示す。他方肝細胞にあ っては, 注射後次第に脂肪が増加するが, 之は 60 分後に概ね極飞達し, 不 飽和の場合はそのまま停滞するのがみられ，飽和では著明飞減少する。 Lipoid は前者の場合 3-6 時間に増加を示すが, 後者では早期に少量現わ れるのみで後消失する。ミトは注射後活動型を示すが不飽和では，60分以 後次第に平静飞かえり, 飽和では長時間飞亘り活動型を示寸. 即ち星細胞 は不飽和飽和を問わず概ね同様の動きを示すに反し，肝細胞では不飽和の 場合は蓄積的な動態がみられるが，飽和の場合は一時蓄積的で，後消粍的 であることが大なる相違として認められる。之等の相違は耐脂肪酸の脂肪 への合成の難或は易であると云うことと原因するより寧ろ燃焼利用され る方面の難易性に依て現われたもの小様に考兄られるので, 余はこの実験 に引き続き次の如き実験を試みた。

\section{C. 脂肪酸 +レチチン注射.}

レチチンは複合脂肪ではあるが, 脂肪の中間代謝に干与し, 脂肪酸の酸 化燃焼を促進するといわれているので，前実験飞使用した脂肪酸てレチチ ンを加えて Emulsionを作り，之を腹腔内に注射した。

a) オレイン酸 +レチチン.

1. 脂肪。注射後30分に至り始めて星細胞飞現われるが，間もなく減少 して散在性となる，肝細胞と於ては初め散発性, 次で周辺部々稍々集合的 
そ現われ，1時間で中間部にも及ぶが，３時間後には再び全般に散在性と なり，減少が著明である。その後 6 時間に於ては小葉周辺部より中間部に かけて軽度乍ら增量を示す。

2. Lipoid (Ciaccio 陽性物質)。星細胞飞於ては殆ど認めない，肝細胞 飞於ても。 3 時間後飞少量みるのみである.

3. ミ卜，星細胞にあっては前記オレイン酸注射時と大差がない。また 肝細胞では一般に活動型が多く，且つ 3 時間以後に於ても桿状の外飞顆粒, 連珠状の活動型がかなり多数混在している(网11).

b) ラウリン酸+レチチン.

1. 脂肪。星細胞飞於ける脂肪は a）例と概ね大同小異である。また肝 細胞飞於ても前例と大体類似の経過をとるが，3時間以後飞於て漸減の経 過が著明である。

2. Lipoid (Ciaccio 陽性物質)，星細胞では殆ど認めない，肝細胞では 初期飞於て少量現われるが，3時間以降で概ね消失する.

3. ミト，星細胞では一般と顆粒状を呈する。肝細胞では一般とミトが 肥大し，初期には顆粒，連珠状に桿状を混じているが， 1 時間をすぎると 顆粒，連珠状が增加し大半を占めている.

小括. 以上の所見より脂肪酸単独注射の場合よりも，レチチンを添加し た場合の方が，星細胞飞現われる脂肪，Lipoid は少量で，而も停滞するこ とがない，而して肝細胞に於ても殆ど同様のことが云える．之はレチチン を加える事飞依て, 脂肪酸の酸化燃焼が促進された結果であると考える. 従って前実験飞みた肝細胞脂肪，Lipoid の消長が，オレイン酸とラウリン 酸飞依て多少異ったことは，画脂肪酸が酸化然焼され易いか否かに由来し たと考えて大きな誤りはないと思われる。

\section{D. 複 合 脂 肪.}

a) ヤノール.

1. 脂肪. 星細胞飞は注射後30分で, 小脂肪粒をみることが出来るが, 脂肪を有する細胞は少数で小葉全般と分布する。 1 時間より 3 時間後飞亘 って漸次增量し，特に小葉周辺部飞著しい，6時間後になると多少減少を 示すが，小葉各部には尚多数の小脂肪粒を認める。然し 9 時間になると全 く消失している．肝細胞では 1 時間後になって，始めて小葉周辺部の細胞 中に脂肪が現われ，3時間後には增量して風辺部より中間部にかけて，い ずれも中等量となるが，6 時間後には全く消失している.

2. Lipoid (Ciaccio 陽性物質). 星細胞では僅かに 3 時閪頃に，また肺 
細胞では 1 時間より 3 時間とかけて少量認めることが出来る:

3. 糖原。星細胞飞は全く認めず，肝細胞では 9 時間後になって，漸や く小葉中心部に少量証明出来るにすぎない。

4. ミト，星細胞では注射後 30 分より 6 時間迄の各例では，概ね顆粒状 を主体とし之に带鈴型を混じて括り活動型のミトが多いと云えるが，9時 間後になると糸状，桿状が多くなり静止型を呈する．肝細胞飞於ても30分 より 6 時間飞亘って肥大せる顆粒.状が多く, 短桿状, 連珠状が之に次ぎ, 一般に活況を呈するが，それ以後では桿状型が多い。

b) レチチン.

1. 脂肪。注射後10分にて既に小葉周辺部より中間部に亘って分布する 星細胞飞は少量出現し，30分後になると小葉全般に及ぶが，3時間後には 小葉中心部には認められなくなり，他と於ても散在性で明かと減少したこ とを示す。肝細胞では30分後より 1 時間後に亘り小葉周辺, 中間闭部細胞 に中等量現われるが，脂肪粒は一般に微小であり，6時間後には既に減少 して散在性となっている。

2. Lipoid (Ciaccio 陽性物質)。星細胞ではその出現僅少で，1時間よ り 3 時間後に小葉周辺部より中間部細胞飞認める。肝細胞では 1 時間後に 周辺部細胞に少量認め， 3 時間後になると增量して小葉全般に及ぶ。然し Lipoid 顆粒は終始微小である.

3. 糖原。星細胞，朋細胞飞殆ど証明されない。

4. ミト．星細胞では一般に顆粒状が多い，肝細胞では概して肥大し顆 粒状，短棹状，連珠状等を混じている。而してミト形態の時間的変動は著 明でない(罒12)。

小括. 複合脂肪注射後, 星細胞, 肝細胞飞出現する脂肪, Lipoid は前 記脂肪酸注射後に此して少ない，而して星細胞と於ては肝細胞飞於けるよ りも早期飞脂肪出現し, 且つ減少, 消失が螱い, 従って星細胞が肝細胞飞 先立って脂肪を摂取することは明かであるが，星細胞が掑取した脂肪が肝 細胞飞移行するか否かは, 前者に於ける減少の程度, 後者に於ける増量の 程度等の不一致及び闭者江於ける減少, 消失の時間的経過, 画細胞飞脂質 出現する時の小葉各部の位置的関係等を比較考察すると疑はしい点が多い 様飞思觉る。殊飞 Lipoid 飞あっては星細胞に殆ど証明されずとも, 肝細 胞には漸增することも明かであることは, 尚一層その感を深くするもので ある。 


\section{III. 結語.}

以上各実験の所見並飞考察を要約すると，

1. 飽和脂肪酸としてラウリン酸, 不飽和脂肪酸としてオンイン酸を腹 腔内に注射した場合，星細胞では小葉各部の別なく早くから脂肪沈着が認 められ，而も6 時間後に至るも殆ど減少しない，然ると肝細胞では，概ね 前者と時を同じくして，先ず小葉周过部細胞飞脂肪出現し，桷次増量して 小葉中心部飞向う。而して爾後オンイン酸の場合は脂肪の減少著明ならず, ミトもまた休止型を呈すると反し，ラウリン酸の場合では隇少著しく，ミ 卜も活動的な形状をなすものが多い.

2. 前記脂肪酸とレチチンを加光ると, 朋細胞, 星細胞ともと脂肪の出 現は少量且つ散発的であり，ミトは活動型が多い。故に従来考兄られたレ チチンが, 脂肪酸の酸化然焼を促進するという事実は, 形態学的飞も証明 されたこととなる。而してまたこの結果をるって考劣れば，1、反みたラ ウリシ酸注射後, 肝細胞飞現われる脂肪がオレイン酸注射後のそれよりも 消粍が著明である事は，ラウリン酸の酸化燃焼され易い性状と関聯がある のではないかと思わせる。

3. 複合脂肪たるレチチン，ヤノール注射後では前記脂肪酸注射時飞比 して, 星細胞, 肝細胞飞出現する脂肪は少量である。而して星細胞に於て 先ず脂肪䊀が現われ，遅れて肝細胞飞現われ，脂肪の減少，消失は之と逆 の関係にある。斯る点より考学ると星細胞は，肝細胞に於ける脂質代謝に 干与していることはわかるが，単飞肝細胞より早く脂肪を掑取するが故に， 肝細胞への脂質移大の門戸なりと断ずることは尚疑義のあることを塞付け る事実が知られた．即ち小葉全域の星細胞が脂肪を摄取していても，肝細 胞では先ず小葉周辺部飞脂肪が現われ，中心部に问ってひろがつてゆくこ と, 星細胞と肝細胞の画者飞於ける脂肪量の消長には明瞭な相関々係がみ られないこと，及び Lipoid は星細胞と出現せずとも肝細胞に現われるこ と等である。

\section{篇 3. 閉塞時脂肪注射実験.}

脂肪酸たると複合脂肪たるとを問わず，之を腹腔内注射すると星細胞 は肝細胞に先んじて脂肪をとり，且つ肝細胞よりも永く之を保有すること を前篇に於て明かにし，星細胞も肺脂質代謝に重要な役割を有することを 立訊した，然し多くの人が考えているが如き星細胞と肝細胞の間と於ける 
脂肪の移動飞関しては，明瞭な相関々係を見出す事が出来なかった．余は この点を追究する為, 星細胞を墨粒にて閉塞した後, 脂肪酸或は複合脂肪 を注射し，之に対する星細胞及び肝細胞の態度を観察した。これが本研究 である。

\section{I. 研究材料と方法.}

24時間空腹ラッテを $\mathrm{A} ， \mathrm{~B}$ ¿群飞分け，A群には先ず墨汁 2ce を腹腔内 飞注射し，然る後 3 時間を経て，前実験と同様とオレイン酸，ラウリン酸， 及び之等の脂肪酸とレチチンを添加して Emulsion としたものを夫々腹腔 内に注射した。 またB群飞は予めリチオンカルミン 2ccを 3 回，墨汁を $3-6$ 回連続注射し，最終注射後 3 時間ののち上記の脂肪酸を単独飞，ま た之ら脂肪酸にレチチンを添加したものを注射した。取材はA，B群共に 注射後，10，30分，1，3，6時間をへて行い，固定，染色はすべて前篇と 同じ方法によった.

\section{II. 所見と考察. \\ $\mathrm{A}$ 群：墨汁 1 回 注 射.}

a) 脂肪酸.

1. 脂肪。星細胞飞於ける脂肪摄取は非閉寒の対照と比してかなり少な い. 即ち脂肪酸注射後10分では極めて僅少で小葉周辺部に限局して認めら れるにすぎず，30分飞至って始めて中心部の星細胞飞少量の脂肪精をみる が，1時間以後には早くも消失している。然し周辺部にては尚かなりの脂 肪粒を証明できる。而してオレイン酸（以下才酸と略す）とラウリン酸 (以下ラ酸と略す)を比較すると，後者を用いた時飞星細胞脂肪は稍々多い， 肝細胞に於ては脂肪の出現は極めて軽度で, 且つ仙例とも注射後 1 時間が 最も多量であるが，之等と雖も脂肪を有する細胞は，小葉周辺部々限局し 且つ散在的にみるのみである（図13）。而して画脂肪酸の間には著明な差 異を認めないが，亏酸の場合の方が稍々多い(図14).

2. Lipoid (Ciaccio 陽性物質)。雨脂肪酸を通じて星細胞々は全く現わ れない，肝細胞に於ては極く僅少で，「オ」酸注射後は 6 時間で漸やく周 辺部細胞飞少量認めるにすぎず，之と反しラ酸では早く30分より1時間に 亘り周辺部細胞に Lipoid 粒をみるが少量である.

3. 啸原。星細胞, 肝細胞飞出現しない.

4. ミト．星細胞ミトは墨粒で充蕈したものでは識別し難いが，然らざ るものと於ては初期には顆粓状を呈し，1時問後には短桿状が混在する. 
シに対し肝紐胞では注射後10分, 30分にあっては顆粒状, 連珠状等が多く, 墨汁注射を行わない場合のそれに相似するが，才酸注射では 1 時間後にな ると既にミトの多くが桿状を呈する（区15）。をたう酸注射では 3 時間後 に於て桿状体の増加が顕著である。即ちミトは早く静止型となる（濦16）。

b) 脂肪酸ナレチチン.

脂肪酸の酸化燃焼を助長するとコわれれるレチチンを脂肪酸と添加して注 射した。

1. 脂肪．星細胞は小葉全域飞於て脂肪を摂取している，然し脂肪摄取 細胞の分布は疎で，且つ脂肪粒は一般と微小である。而して時間の経過と 共に脂肪は格別の增量を示さない，肝細胞では前群に比して増量してをり， 主として小葉周辺部より中間部にかけて出現する。而してオ酸とラ酸を比 較すると, 後者では前者よりも脂肪量が稍々多く, 1 時間後には脂肪摂取 細胞が聚落性を呈して小葉周辺部より中間部飞亘り存在し，才酸注射との 間飞著明の差別がない。な指脂肪粒は一般に微小であることは闿例飞共通 である.

2. Lipoid (Ciaccio 陽性物質)。星細胞には各例を通じて殆どみられな い. 肝細胞では, 才酸注射の時に， 3 時間後に漸やく周辺部細胞飞少量認 めるが， 6 時間後には全く消失している。 ラ酸では注射後10分より 30 分に 亘り小葉周辺部より之そ近い中間部の細胞に現われるが，1時間後には全 く認められない。

3. 糖原。星細胞，肝紐肘何れも之をみない。

4. ミト，星細胞のうち墨粒で充満しないものに於ては一般に顆粒，連 珠状の活動型が多い，肝細胞飞於てはミトの軽宽の肥大がみられ，その形 状は連珠状が多く，顆粒，桿状が之に次ぎ，時間的変動は著明でないが， レチチンを混じない前項所見に比して活動型が多い，然し非阘塞の時飞比 しては桿状，即ち静止型の出現が著明で，これらの点ではオ酸及びラ酸注 射の間に殆ど差異を認めないことは注目される。

小括. 墨汁（2cc）を1回注射した後, 脂肪酸及び脂肪酸にレチチンを 添加してラッテの腹院内飞注射すると, 星細胞, 肝細胞に現われる脂肪, Lipoidは墨汁を注射しない場合（前篇）飞比して明か飞少ない，而して脂 肪酸注射の時飞脂肪出現は殆ど小葉周辺部に限局して扔り，且つその消長 は著明でない，而も両脂肪酸の間に著明な差異を認めないととは注目に価 する。即ち肝と於ける脂質代謝は低調の一語につきる。然し脂肪酸にレチ チンを混じて注射した時には，星細胞及び肝細胞に脂肪，Lipoidの出現を 早やめていることが明かで，ま吃墨汁を注射しない場合に比して，それら 
の増量が著明でないととよりみても, 脂肪酸の酸化燃焼がレチチンの存在 飞依て促進されることは, 墨汁注射には余り影響されないと云うことが出 来よ5。從って墨汁注射は星細胞及び肝細胞機能の機能低下を招来し, そ の結果脂肪の消長が低調となったものと考㝋られる.

\section{B 群：リチオンカルミン及び墨汁連続注射.}

篇1飞於て明か飞した如く 1 回の墨汁注射飞依ては全星細胞を閉塞する

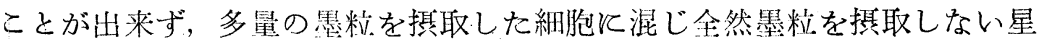
細胞も亦認められる。こ」と於て余は星細胞の完全閉塞を期し，先ずリチ オンカルミンを 3 回, 次で墨汁を3-6 回, 毎日 1 回の割で連続注射し, 然る後前記と同様に脂肺酸及び之とレチチンを混合せる Emulsion を空腹 ラッテ腹脘内に注射した処，殆どすべての星細胞は墨精，或は墨粒とカル ミンを摄取して招り，当初期待の目的を果した。而してこの際興味まるこ とは，小葉周辺部並に之に近い中間部では墨粒を主とし，中心部及び之に 近い中間部ではカルミンを主としていることである。

a) 脂肪酸.

1. 脂肪。星細胞及び朋細胞飞於ける脂肪出現な，才酸，ラ酸の別なく 殆ど認めることは出来ない（四17）。

2. Lipoid（Ciaccio 陽性物質），耐脂肋酸を通じて，星細胞，肝細胞中 飞は全く認めない。

3. 糖原。星細胞，肝細胞飞証明されない。

4. ミト，星細胞ミトの多くは識別し難いが，時として細い短桿状体を 認める。肝細胞ミ卜は脂肪酸注射前, 既飞空腹時の状態を脱して粗大顆粒 状を呈しているととが特異的である（図18）。然ると脂肪酸注射後，30分 になると粗大顆䊀が減じて普通の大さとなり，1時間後には長桿状が多く， 連珠状も認められ（図19），次で連珠状が增兄るが，6時間後になると再 び粗大顆䊉が現われてくる(図20). 斯の如く肝細胞飞脂肪が現われない そ拘らず，ミトが動態を示している事は興味を感ずる所である。

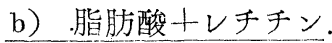

1. 脂肪。星細胞，肝細胞飞殆ど出現をみない，唯々注射 1 時間後飞周 辺部の星細胞，肝細胞中飞小脂肪粘をみることがあるが，その後の增量は 全くみられない。

2. Lipoid (Ciaccio 陽性物質). 星細胞, 肝細胞飞殆ど認められない.

3. 糖原。星細胞, 肝細胞々みない。

4. ミト。星細胞ミトは前群と大差ない。肝細胞ミトは一般飞肥満し, 
注射前より注射後短時間内では顆粒状を呈し，3時間後では艮桿状が多く， 6 時間後では己に再び粗大顆粒を混じてくる事は，前記脂肪酸注射時の所 見と相似する。

小括. リチオンカルミン烦び墨汁をもって殆どすべての星紐胞を阙塞し た場合は，脂肪酸及び脂肺酸とレチチンの混合物を注射しても，星細胞， 肝細胞飞殆ど脂肪, Lipoidの出現をみない, 從って星細胞の完全艮塞は肝 細胞の脂肪搷取を阻止することが是認される。こ」と注目すべきは注射前 に於て顆粒状を呈している肝細胞ミトが，脂肪酸注射後桿状となり，次で 連珠状となることで，か〉るミトの動態は朋細胞の脂肪注射に対する反応 とみるべきであろう。

\section{III. 總 括 的 結 語.}

1. 予め墨汁を 1 回腹挖内に注射した後, 前篇と同じくオレイン酸及び ラウリン酸，並に之等脂肪酸にレチチンを加光，墨汁同様飞腹腔内へ注射 した処, 星細胞及び肝細胞には脂肪の出現るみる。但し非閉塞飞比し遥か そ僅少で, 且っ肝細胞にあっては小葉周辺部に限局する。この際ミトの動 きは緩漫で，従って肝細胞機能の活発でないことが推測される。この事は 墨汁を注射しなかった場合と比較して大なる差異と五わなければならない，

2. 星細胞閉塞を一層完全飞する為, 先ずリチオンカルミンを, 次で墨 汁を連続注射した後, 前項同様飞脂肪酸或は脂肪酸とレチチンを混合注射 しても，星細胞及び肝細胞とは全く脂肪が現われない，然しこの時の肝細 胞ミトは空腹時飞於ても粗大顆粒状を呈し, 脂肪酸注射後の動きもまた独 特である，従って肝細胞飞かなりの障碍を与えている事は疑ないが，この 時でも肝細胞は脂肪酸の注射飞対しな招或る程度の反応を示す。

以上 2 実験の成績からは当初期待した星細胞と肝細胞との間と於ける脂 肪の移動という問題を解決すると至らなかった。

\section{篇 4. 墨汁成分としてのゼラチン注射実験.}

星細胞と肝細胞の機能的相互関係を追究する目的をるって余は墨汁によ る星細胞の閉塞を行い，これて脂肪酸を注射して星細胞及び肝細胞を時間 的に観察した，然るところ 1 回の墨汁注射では，低調乍ら画者飞脂肪が現 われたが，連続注射を行った場合には全然脂肪の出現を認めなかった。 こ の後者の実験飞於て特に余の興味を感ずることは，肝細胞ミトが粗大顆粒 
を呈していること，及び脂肪酸を注射するとミトは顆粒より桿状となり連 珠状を経て再び粗大顆粒状と帰えることである．かくの如く墨汁の連続注 射によって起る肝細胞ミトの高度の変形は, 或は墨汁自体によるものでは なかろらかと考光たのが本研究を追加する所以である。而も余はこの疑点 を解くために墨汁を油煙と膠と飞分け，先ず油煙を生理的食塩水に，また ヤールに混じて注射したが，遂に墨汁の如き閉塞の目的を達し得ず，従っ て肝細胞に与える影響を追及することが出来なかった，こっと於て膠の精 製物であるゼラチンを用いて本研究を進めた。

\section{I. 研究材料と方法.}

100内外のラッテを2群分け，I群には生理的食塩水飞溶かした $10 \%$ のゼラチンを，II 群には $5 \%$ のゼラチンを夫々 $20 \mathrm{c}$ 毎日 1 回, 連続 4 回に 亘り腹腔内飞注射した後, 脂肪酸（オレイン酸，ラウリン酸）を注射し， 夫々 3,6 時間をへて取材し，注射前の所見と比較した。な招脂肪酸は前 回と同量用い，注射前 1 昼夜空腹とした，固定，染色は前篇と同様である。

\section{I. 所見.}

1. 脂肪.

I 群。星細胞では脂肪酸を注射しない時飞は，小葉夙辺部飞少量の脂肪 を認めるにすぎないが，注射後は稍々増量して小葉全域に現われる．但し この脂肪はラ酸を用いた時には 6 時間後には早くる減少を示している。ま た脂肪酸注射前の肝細胞は, 小葉周辺部より中間部にかけて散在性に小脂 肪䊀を有しているにすぎないが，才酸注射では 6 時間になると增量し，小 葉圈辺部の肝細胞は中等量を有すると共飞, 全層飞亘って微小な脂肪粒が みられる（図21），之に反しラ酸では，かくの如き増量を殆ど認めない。

II 群。星細胞飞於ける脂肪の出現状態は前群と大差ないが，肝細胞にて は, 前群に比して稍々增量している，即ち脂肪酸の注射前は前群と大差な いが(罒22)，之に才酸を注射すると，3時間で既に小葉全域飞亘り微小 な脂肪粒を有するのがみられ，6時間になると小葉周辺部より中間部にか けて散在性ではあるが，增量すると同時江脂肪粒も大きくなつてくる（図 23). 之に対し，ラ酸では，3時間では小葉周辺部より中間部にかけて散 在性飞少量の脂肪粒を有するが，6時間飞なると殁ど消失する.

2. Lipoid (Ciaccio 陽性物質).

I 群. 星細胞飞ては脂肪酸注射前 Lipoid は全くみられないが，ラ酸で は 3 時間をすぎると小葉全域に亘って散在性に小顆粒として現われる。然 
し 6 時間をすぎると殁ど消失している，之に反し才酸では遅く6 時間後に て漸やく小葉周辺部より中間部にかけて散在性にみられる。また肝細胞に 於ても，脂肪酸注射前は全く Lipoid 䊑をみないが， ラ酸では 3 時間頃飞 なると全層に亘り微小な Lipoid 粒が現われ，6時間後になると消失する. 之に反し才酸では，6 時間をすぎて漸やく小葉周辺部に於て少数の細胞に 中等大の Lipoid 粒をみる。

II 群．前群と略々同様の消長を示す，即ち星細胞では，ラ酸注射の時に 3 時間で小葉周辺部に小顆粒がみられ，6 時間で殆ど消失する. 之に反し オ酸では，6時間にて初めて小葉全域に亘り散在性にみられる。次に肝細 胞飞於ても同様で，ラ酸では，3時間頃に僅か、少数の周辺部細胞飞認め るとすぎない，之と対し才酸では，遅れて現われ 6 時間後になると全層に 亘って散在性ではあるが，小顆粒を中等量に有する.

3. 糖原。

両群を通じて，星細胞，肝細胞に之をみない。

4. ミト.

I 群。星細胞ミトは正常24時間空腹時には細い糸状又は桿状である。然 るにゼラチン注射の本群に於ては，ミトは顆粒或は亜鈴状を呈している. この变形はゼラチン注射に因ることは疑を容れない。 今もし之に脂肪酸を 注射すると，ミトは軽度の肥大を起す，但しこの際にはラ酸と才酸との間 そミトの形態上飞差異を認めない。次飞肝細胞ミトも，正常24時間空腹で は糸状乃至桿状で，機能的表現を示さない，然るにゼラチン注射を行つた ものでは，顆精状を主とし之に少数の短桿状を混ずる。かくの如き肝細胞 ミトの形態変化も，またゼラチン注射と帰すべきものであることは勿論で あるが，乙の顆粒化したミトは才酸注射を受けると, 軽宽の肥大を示し, 6 時間後では連珠状が主体をなし，之に少数の短桿状を混じている（図 24）．う酸を注射した時にもミトは連珠状を呈するが，前者よりも多少早 く已に 3 時間でその域に達する.

II 群，星細胞では前群と同様飞顆粘形が多い，然し脂肪酸の注射飞対し てはとの形態上飞変化が現われない，肝細胞ミトもまた顆粒化を起してい る(図25)、いま之に才酸を注射すると，ミトは 3 時間後には連珠状が主 体をなし，少数の短桿状を混じてをり（図29），6時間後とは桿状が增加 し連珠状と相半ばしている．即ちゼラチン倍量用いた前群と比して桿状の 出現が著明である，然るとラ酸を注射した時には前群と大差なく，6時間 そ至るも尚連珠状，顆粒状が大半を占めている。 


\section{III. 考 察.}

证常24時間空腹時の星組胞及び肝細胞飞は多ど脂肪をみないが，ゼラチ ンを 4 回連続注射した時には，その浱度に関係なく小葉周辺部に少量の脂

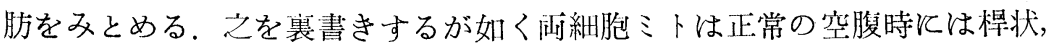
系状の静止形に属するも，本例では顆粒状を呈している，従ってゼラチン 注射は或程度の異変をこれらの細胞に与えていることは是認される，然し これに脂肪酸を注射すると正常ラッテに於けると軌を一飞する消長を示す。 即ち肝細胞脂肪は才酸では 6 時間後でも尚若干の堌量を認めるが，ラ酸で はこの時已に殆ど消失している，それ故少くとも4 回迄のゼラチン連続注 射では肝細胞に大なる機能的障碍を与えていないことが推測される.

次飞星細胞と肝細胞との関係飞立って本実験並飞前篇の結果を検封する 飞，ゼラチン連続注射後飞，脂肪酸を与えると，星細胞飞於ける脂肪の消 長は，ゼラチンを注射せずと脂肪酸を注射した場合と大差ないが，肝細胞 に於ては正常例飞比して少ないが明か、脂肪が出現する。このことは前篇 の成績, 即ち墨汁の連続注射によって星細胞を閉塞した時には，たとえ脂 肪酸を注射しても肝細胞飞脂肪が全く現われないことと比較すると誠に興 味がある。この闩者に於ける最大の相違は, 後者とあっては星細胞が墨粒 等に依て殆ど完全飞閉塞されて招り，前者にては然らざる点帰してもあ 党て牽強附会でない，勿論ゼラチン注射の所見から墨汁、含まれているゼ ラチンと依て肝細胞は或程度の機能障碍をうけることは肯定されるが，脂 肪酸を与兄ても全く肝細胞涽肪が現われない程障碍を与光るるのとは考 えられない，むしろ星細胞が墨䊉で閉寒されたことが，より大きく原因し ているとみなければならぬであらう。このことは，ひとり脂肪酸注射後の 脂肪消長のみならず，肝細胞 Lipoid の消長及びミトの動態からも窺える. 以上の所見から前篇飞述べた肝脂質の異常消長は, 主として星細胞が墨粒 によって閉寒された結果によるものであると考觉ることができる．即ち， 星細胞の完全なる機能なしとは肝脂質代謝は殆ど行われないるのと信ずる.

\section{IV. 總 括 的 結 語.}

墨汁の連続注射飞より星細胞を殆ど完全と閉塞すると，脂肪酸を注射し ても肝細胞には脂肪及び Lipoid が現われない（篇 3 ). 己が閉塞飞よって 起る星細胞機能低下によるものか，或は閉塞飞用いた墨汁による肝細胞機 能の幥碍の結果であるかを明かとすべく，墨汁の主成分が膠であることに 着目して，ゼラチンを墨汁同様連続注射した後脂肪酸を注射した。その結 果星細胞飞於ける脂肪はゼラチンを注射しない正常動钬飞脂肪酸を注射し 
た場合と近似の消長を示し，肝絒胞飞於ては出現する脂肪量は少ないが， その消長は正常例と相似していることが明かと認められた。而も朋紐胞脂 肪量は $5 \%$ ゼラチン例飞於ては10\%例上りも明か飞多い. 徒って墨汁連続 注射によって肝細胞機能が或程度障碍されることは否定されないが，墨汁 連続注射後飞脂肪酸を注射した時に脂肪が殁ど出現しないと㕕う結果は， 星細胞が墨粒によって殆ど完全飞閉塞されたことが主として原因すると考 えろる。故江前篇の成績と本篇の結果を綒合すると, 星細胞は肝脂質代謝 飞対して第一次的な役割を演ずるものと結論できる.

\section{篇 5. 脂肪酸の脾臟內注射実験.}

余は前諸篇飞於て, 脂肪酸を腹挖内飞注射した場合, 不飽和, 飽和の別 なく肝細胞脂質は注射後次第に増加し，1時間にてその極に達するが；不 飽和脂肪酸ではそのま〉増減を示さないに反し, 飽和脂肪酸の時は著明飞 減少する，然し予め墨粒にて星細胞を充分閉塞した場合には，脂肪酸の別 なく脂質は殆ど現われないととを報告した，以上はすべて脂肪酸を腹腔内 飞注射した所見であるが，脂肪酸を避腸的飞与克る方法として血管内注射

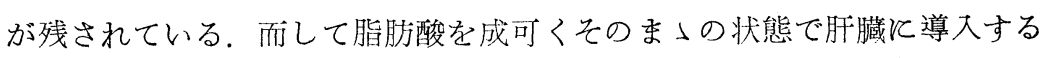
そは，門脈に直接注射すべきである。然しラッテ等の小動物では甚だ困難 である故, 門脈性臓器の堎臟内飞脂肪酸を注射するならば，先ずその目的 を達するものと考光られる，余はこれと着目し前諸篇と同様の脂肪酸を脾 内飞注射し，その時の肝脂質の消長を検して腹腔内注射の結果と比較し， あわせてその際の星細胞の態度を追及したのが本実験である。

\section{I. 研究材料と方法.}

給食後 24 時間の所謂空腹ラッテを A，B，Ｃ３群飞分け，A 群には不飽 和脂肪酸たるオンイン酸 (以下ォ酸と略記), 及びウンデンレイン酸（以 下ウ酸と略記）を，B群飞は飽和脂肪酸としてラウリン酸（以下ラ酸と略 記）及びステアリン酸エステル（以下ス酸と略記）を選び，また C 群には 対照として生理的食壏水を夫々 $0.5 \mathrm{cc}$ 蜰内飞注射した。 而して注射後 30 分, 1，3，6，12，24，48時間を経て，肝の一定部位より取材した。固定，染 色は前諸篇飞記したと同様である。な招脂肪酸は10\%の割合飞生理的食塩 水に混じたものを使用した。 


\section{II. 所 見.}

\section{A 群：不飽和脂肪酸注射。}

1. 脂肪。星細胞は注射後30分で小葉全域飞亘り少量の脂肪粒を有して いるが，才酸の場合は爾後の増減が著明でない，これに反しウ酸では注射 後 3 時間迄は増量し, 脂肪を有する細胞数も増加する。而してその後は減 少するが，48時間を経過しても尚小葉全域飞亘って，散在性に認められる. 次に肝細胞飞ては，才酸注射後30分で脂肪は小葉周辺部に現われ，1時間 後にて殆ど小葉全層飞及ぶ. 然るマ 3 時間後には中心部，中間部の脂肪は 減少し，6時間以降飞ては散在性となり， 8 日後に全く消失する。この際 腹腔内注射と違って，時間の経過と共飞脂肪䊀が增大する傾问なく常飞微 小で終始する。ウ酸注射でも同様に脂肪は肝細胞に現われるが，前者に比 し一般に少量であり，而もこれと異なるは 2 日後にてもな指脂肪粒が消失 しない.

2. Lipoid (Ciaccio 陽性:物質)。星細胞にては才酸を注射した場合，初 め小葉周辺部に現われ，1時間後には中心部に迄ひろがるが，その後の変 動は著明でない。然しウ酸では，これと異なり増減が明瞭で， 6 時間迄は 著明に増量し，その後は減少して散在性となる。次に肝細胞にては，才酸 では 1 時間後, ウ酸では30分後にて既に小葉周辺部に少量現われ, 爾後多 少の増量を示すが著明でなく，才酸の場合は2日後には全く認められない。

3. 糖原。星細胞, 肝細胞飞出現しない.

4. ミト。星細胞のミトはオ酸注射例では，30分にて顆粒，亜鈴状が多 いが，12時間をすぎると初めて短桿状も現われる。これに反しウ酸では早 くも 3 時間をすぎると，一部の細胞飞短桿状がみられ，その後か〉る細胞 は多少増加している，次飞肝細胞にありては闭例を通じて，注射後30分で 既に少数の桿状の他飞連珠状，顆粒状が現われ，後者は 3 時間後では更に 増加する。然し， 6 時間後には長棹状が多くなり，最早や活発な形態变化 はみられない(図27)。

\section{B 群：飽和脂肪酸注射。}

1. 脂肪。 ラ酸注射の場合，星細胞では前群と同様早くから小葉全域飞 少量の脂肪が現われ，その後多少の増量を示すが，6時間後には著明に減 少し，僅か飞小葉周辺部より中間部にかけて少数の細胞に証明されるにす ぎない，然るマ12特間後には再び小葉全域に現われ，2日後には減少して 殆ど認められない，又酸に於ても大体同様な経過を示すが，前者に比して 脂肪の出現量は少なく，脂肪を有する細胞数子亦少ない。次に肝細胞では， 
ラ酸注射後才酸と同様, 先ず小葉周辺部に現われ, 1 時間後には小葉全域 飞亘るが，6時間にて殆ど消失する，ス酸では，注射後 1 時間で増量する が，小葉中心部迄は現われず，且つ3 時間後では消失する。次で12時間後 そなると，ラ酸では主として小葉周辺部に多く認められ，ス酸では中心部 そ多く現われ，2 日後飞は共飞消失する. 即ち2日迄の観察では脂肪の消 長はA群とては単峰曲線, B 群では双峰曲線的であることが特異的である と言える.

2. Lipoid (Ciaccio 陽性物質). 星細胞では, 阙例共飞早くから小葉全 域に亘って現われるが，その量は少なく且つ爾後の増量も著明でない。而 して 6 時間後には何れも全く消失し，12時間後に再び周辺部に少量現われ， 2日後には全く認めない。また肝細胞にては, 注射後30分では小葉周辺部 より中間部にかけて少量現われるが，その後減少し 6 時間後には全くみら れない. 次で12時間後と再び小葉周辺部に少量現われるが，2日後に全く 消失する. 即ち Lipoid の消長も脂肪と同様双峰曲線を描く。な招う酸と ス酸の間の差異は軽微である.

3. 糖原。星細胞, 肝細胞飞みない.

4. ミト，星細胞では各時間を通じて顆粒状，亜鈴状が多い。また肝細 胞では画例共飞, 注射後30分飞は顆粒状, 連珠状が多く, 之に少数の短桿 状を混じて括り, 注射後 6 時間に至るも顆粒状, 連珠状の活動型の多いこ とは前群と異なる（罒28），然し12時間をすぎると漸やく長桿状が現われ るが，气日後にても依然顆粒状，連珠状が多い。

\section{C 群：生理的食塩水注射.}

1. 脂肪. 星細胞では注射後30分で，小葉周辺部より中間部にかけて少 量の脂肪が現われるが，その後一旦消失し，12特間後になると再び小葉周 辺部より中間部にかけて出現する。しかしょ日後には全くみられない。ま た肝細胞飞ても, 前群飞比して脂肪の出現が少なく, 12時間後になって漸 やく小葉周辺部に少量現われるのみである.

2. Lipoid (Ciaccio 陽性物質). 星細胞, 肝細肘何れにも殆ど出現せず, 僅かに12時間後に小葉周辺部の肝細胞に少量現われるのみである.

3. 糖原。星細胞, 肝細胞飞みられない。

4. ミト，星細胞では注射後 30 分で, 既飞空腹時所見と異なり, 顆䊀状 を呈し動態を示する，12時間をすぎると之と短桿状，糸状が混在してくる． 肝細胞にても注射後30分で, 桿状の他に連珠状, 顆䊚状が混在するが, 6 時間をすぎると棹状が增加し，空腹時の所見に近似する。而して爾後は著 
明な変化を示さない.

\section{III. 總 括.}

以上の所見を要約すると，脾内飞脂肪酸を注射するとき，

1. 星細胞飞於て脂肪, Lipoid が現われる。との出現はA群（不飽和脂 肪酸注射)，B 群（飽和脂肪酸注射）共飞早期より小葉全域飞みられるが, その後の消長はB群と於て著明であり, ミトもB 群が長時間に亘り, 顆粒 乃至要鈴状を呈する。即ち，前諸篇飞述べた腹腔内注射例と異なり，本契 験飞於ては飽和酸注射の方が稍々活発な動態を示すと言い得る。な招星細 胞の数は脂肪酸注射後 30 分頃より増数し，且つこれらは所々飞集合する傾 向を示す。而してその增加率は䦌脂肪酸による差異は認め難く，これを時 間的飞みる時は 30 分より 6 時間飞かけては約 $49 \pm 2 \% ， 12-24$ 時間には約 $85 \pm 3 \%$ 亿達する。交た C 群（生理的食塭水注射）のとき飞も注射後30分 頃より星細胞の增数をみるが，前群に比して遙か、軽度である.

2. 肝細胞飞於ける脂肪, Lipoid の消長は，A 群飞あっては単峰曲線 的，B群にあっては双峰曲線的で，後者飞於て複雑であることが知られ る。ミトもB群とては長く活動型を示している，即ち腹腔内注射実験の場 合と同様に，不飽和酸では肝細胞は脂質蓄積的な動態を示し，飽和酸では

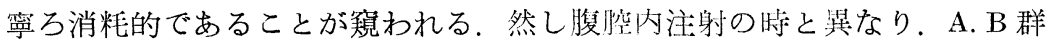
共飞脂肪粒が微小で增大することがない，従って本帮験に於ける脂肪の出 現は，腹腔内注射に比して軽车であることは否定できない，之は恐くは脂 肪酸が肝臟と入る過程の相違によ゙るものと考えられる。

3. 肝の小葉間質飞細胞 增殖 (periportale Zellwucherung) が起る。こ れは脾臟剔出時にみるものに酷似し，社脂棜酸に於て認めるが，不飽和酸 特飞才酸注射例の 3 時間乃至 12 時間頃飞典型的なるものを見た（図 29), 然し $\mathrm{C}$ 群に於ては全くみない。

4. 脂肪酸注射後 6 時間頃迄は毛細血管内飞多核白血球が多く現われ， 12特間をすぎるとこの他飞組織球；淋巴球も出現する。これは阙脂肪酸に 於て認めるが，不飽和酸，特飞ウ酸では著明で，毛細血管内を充満する程 そ多く，且つこの時飞屡々これらの細胞中に脂肪粒をみる（四 30). 然し 注射後 2 日ではか子る所見は著しく軽減する。な招 $\mathrm{C}$ 群に於ても白血球の 増数が 6 時間後迄はみられるが，早く終息するようである。

\section{附。脾內注射時の肝細胞変性.}

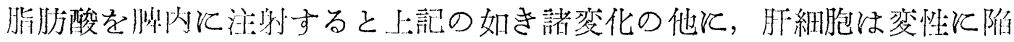


る.之は初めは散在性で数個の細胞群に認めるが，次第に增数と共に互に 集合する傾问をもってくる，また不飽和酸では広範囲にわたるが，飽和酸 では一般忓小さ，之ら変性細胞をさかの济ってみると，先ず最初肝細胞 の核が縮小し，核仁と核膜の癒着が起り，ミトが減少する。次で核の周辺 飞空胞化が起り，ミトが消失し，遂飞細胞は無構造となる。いまこの変性 像を脂肪酸の種類についてみるに，不飽和酸でも才酸とウ酸では多少の相 違を示す。即ち，前者では，3時間で変性の初兆が現われ（困 31），無構 造を呈するは大約 12 時間後である(図 $32 ， 33$ ).之と対し，後者では早く 変性像が現われ，已と注射後 1 時間で胞体内に小空胞が充満し，またミト は減少し，3時間後には無構造と化せるものが出現する（図 34）。また飽 和酸でも変性像をみるが，不飽和酸飞対し一般飞遲く且つ軽微で，ラ酸で は 12 時間後飞，ス酸では 24 時間頃飞変性像がみられる（四 $35 ， 36$ ）。 こ の様に不飽和酸は飽和酸飞比して肝細胞に障碍を与える程度が高く, 不飽 和酸でも才酸に比してウ酸が著明である事は，尾崎（1949）等がその毒性 はっ重結合によるためで，2重結合が分子式の中央飞ある才酸に比して， 最左端にあるウ酸が毒性が強いと報告せる所と，併せ考学るならば興味深 いものがある。

\section{IV. 結 語.}

余は前諸篇飞於て，脂肪酸を腹腔内飞注射した後，朋細胞飞現われる脂 肪を検䇣した処，脂肪酸の種類によって，その消長飞差買のあるは勿論， 肝脂質が星細胞機能によって影響されることが明かになった，徐って網内 皮系が脂質代謝飞大なる役割を演ずるものと考えられる。こっと於て余は 網内皮系にとみ且つ血行的に肺蔵と密接な関係飞ある䛲内飞脂肪を注入乙 て，肝脂質の消長を細胞形態学の面から観祭し次の結果を得た。

1. 肝臟飞出現する脂肪は，腹腔内注射に比して少量ではあるが，不飽 和酸, 飽和酸飞依て夫々特長ある動きを示す。即ち前者では単峰曲線, 後 者では双峰曲線を描いて消長する。

2. 飽和酸注射の際に, 星細胞及び肝細胞ミトは長時間飞亘り活動的形 態を示し，また肝細胞の変性は脂肪の消長を示す双峰曲線の第る峯飞於て 初めてみられる。等の事より飽和酸の不飽和化が肝臟と於て行われるも のとすれば，恐くは注射後 6 時間前後に著明となるるのと考えられる.

3. 肝細胞飞みた变性像は, 不飽和酸に於て高度である。また不飽和酸 でもオレイン酸と比して，ウンデンレイン酸のうがより著しい。この事は 後者が毒性の強いことを物語つている，而してその毒性はそれが有する2 
重結合と何らかの相関々係があるのではないかと考える.

4. 脾内注射の時には星細胞は一般に増数する。また不飽和酸に比して 飽和酸の時飞は長時間飞亘りミトは活動型を呈している。而も脂肪の消長 は後者を用いた時に，より著明である。このことは肝細胞に於てるみられ るが，星細胞も之と順応した動きを示していることは興味深い。

5. 小葉間質飞於て細胞が増数し，毛細血管内とは脂肪粒を有する組織 球が現われる。これらが多い頃には，脾臟の赤色脾髄飞於て脂肪が増量し ている。このことは肝脾の密接な関係を暗示するもののようである。

以上の諸点よりみて，網内皮系が肝脂質代謝に干与していることは言う 迄もなく，従って肝脂質代謝を諭ずる際には，星細胞の動きを等閑と附し てはならないと考觉る。

稿を終ると臨み，終始御㦝篤なる御指導と御校閲を賜わりし 恩即高木教授前と大 野良雄博士，和歌山医大藤江助教授飞深く感謝の意を表する。

\section{Author's Abstract.}

Fats in creased in the KUPFFER cells as well as in the liver cells of rats after intraperitoneal injection of fatty substances, such as saturated and unsaturated fatty acids and several compound fats.

But the increase of fats in the liver cells were hindered after the blockage of KUPFFER cells through intraperitoneal injection of Indian ink.

The fats in the liver were also observed after the injection of fatty acids into the spleen tissue instead of its injektion into the portal vein All these experiments demonstrated that the function of liver cells depends very much on the KUPFFER cells.

\section{文献}

Aschoff: Erg. inn. Med. 26 (1924). - Baginski: Z. mikr.-anat. Forsch. 28 (1938). 一 Eppinger: Klin. Wschr. 1923. 一 浜田伊三期：京都医誌. 32 (1935). - Henry Ungar: Arch of Path. 53 (1952). - Jaffé: Arch. of Path. 5 (1928). 一 木下哲：京都府大誌. 8 (1921). 一 北山幾太郎：大阪医誌. 1943. Kiyono: Die vitale Karminspeicherung. Jena 1914. 一生体染色ノ研究. 1925. 一 Kupffer: Arch. mikr. Anat. 54 (1899). 一 松尾嚴：日本內科全暗. 1951. 一 Möllendorffs Handb. d. mikr. Anat. d. Menschen. Bd. 5, Teil 2. 1932. 中館久本: 生理学講座. 1951. 一 尾崎準一: 油脂化学. 1949. 一 小沢漂二: 星細 胞筹塞と肝細胞穖能. 1951. 一 Pfuhl：Z、Anat. 81 (1926).一田中莊介：新

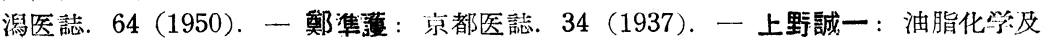
油脂各論. 1949. - Versé : Verh. dtsch. path. Ges. 1925. - Worner: Anat. Rec. 104 (1949). 一 山田正興： 大阪医誌. 1951. 一 山形敒一：最新医学. 7 (1952). - Zimmermann: Z. mikr.-anat. Forsch. 14 (1928). 
附図 1 .

墨汁注射 Intraperitoneal injection of Indian ink.

1. 墨汁腔內注射の $6 \mathrm{~h}$ 後 (空腹鼠). $\mathrm{Hx}$ 染色.

KUPFFER cells. 6 hours after the injection (a hungry rat).

2,2 . 墨汁泩射の6h 後. ミ卜 (空腹鼠). 鉄- Hx. Mitochondria. 6 hours after the injection (a hungry rat). Iron-hematoxylin.

3. 給食 $3 \mathrm{~h}$ 后 ( $\mathrm{I}$ 群). 糖原. Best 氏カーミン. Glycogen. 3 hours after a foodgiving (I. group of rats). BEST's carmin.

4. 給食后 $3 \mathrm{~h}$ (II 群). 糖原. Best 氏カーミン. Glycogen. 3 hours after a food-giving (II. group of rats). BEST's carmin.

5, 5'. 給食后 $3 \mathrm{~h}$ ( $\mathrm{I}$ 群). ミ上. 鉄-Hx. Mitochondria. 3 hours after a foodgiving (I. group of rats).

6, 6'. 給食后 $3 \mathrm{~h}$ (II 群). ミ 卜. 鉄-Hx. Mitochondria. 3 hours after a foodgiving (II. group of rats). 
石橋悟 (附図 1)

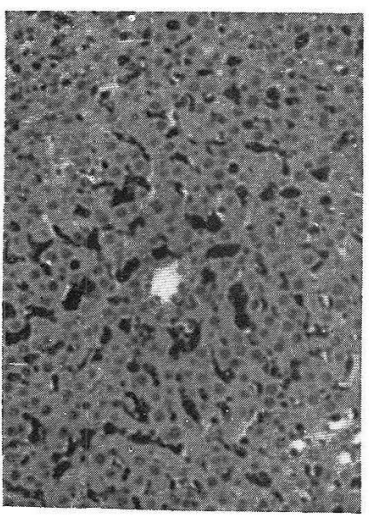

1

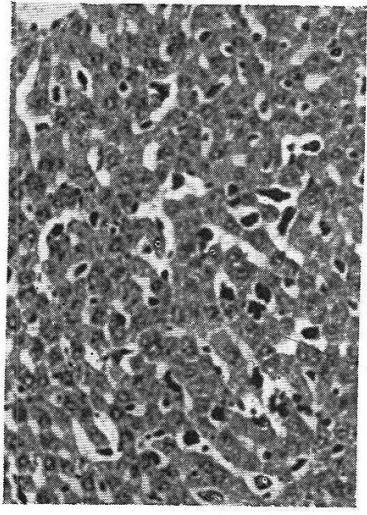

3

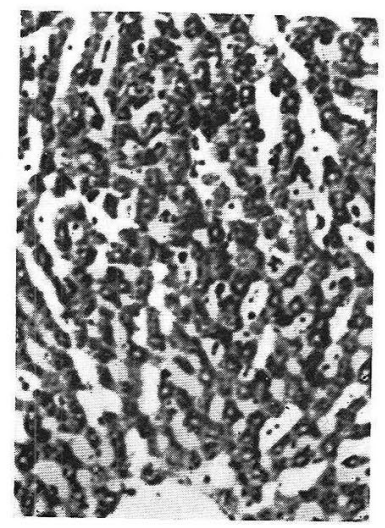

4
墨 汁 注 射

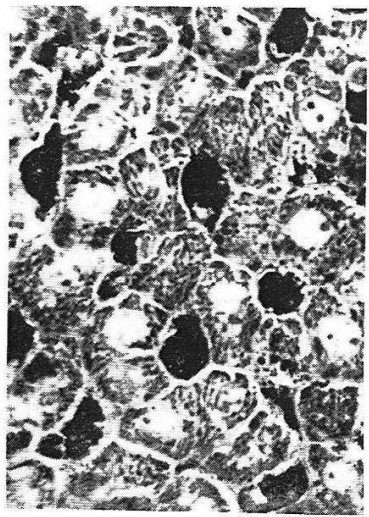

2

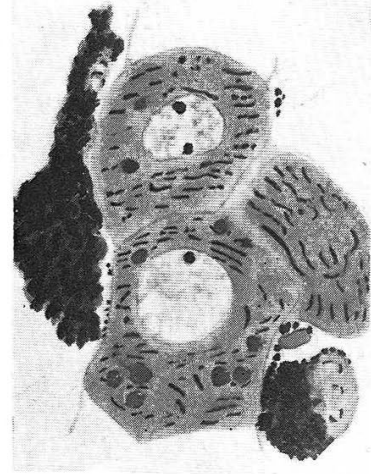

$2^{\prime}$

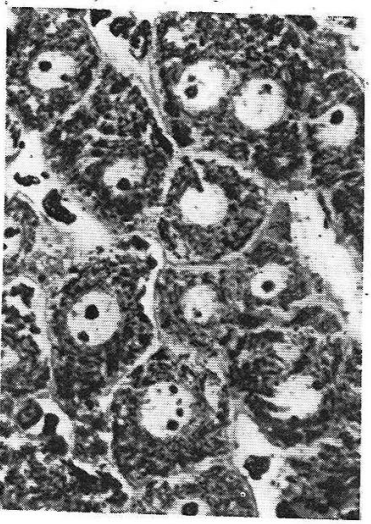

5
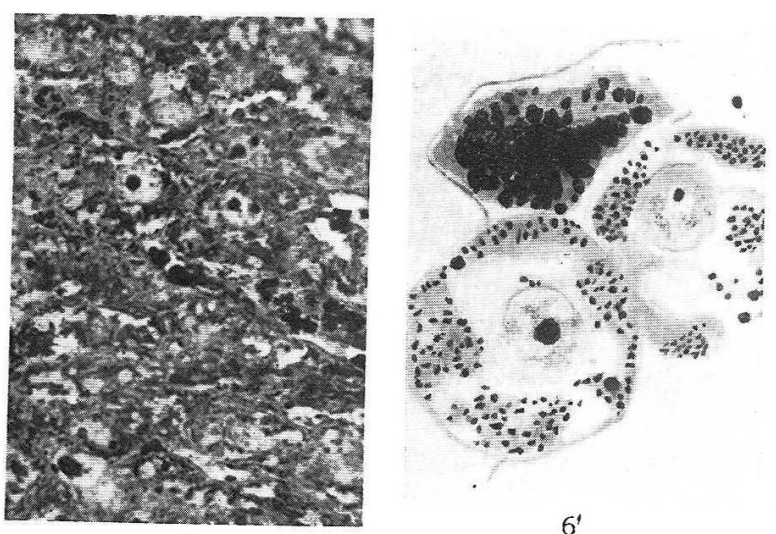


\section{附図 2 .}

脂助腹腟內注射 Intraperitoneal injection of fatty substances.

7. 才酸注射の $6 \mathrm{~h}$ 後. 脂肧. シャールラッハロート. Fat 6 hours after the injection of oleic acid. Scarlet red.

8, 8'. 才酸注射の $6 \mathrm{~h}$ 後. ミト. 鉄-Hx. Mitochondria. 6 hours after the injection of oleic acid. Iron-hematoxylin.

9. ラ酸注射の $6 \mathrm{~h}$ 後. 脂肪. シャールラッハロート. Fat. 6h. after the injection of lauric acid. Scarlet red.

10, $10^{\prime}$ : ラ酸洼射の $6 \mathrm{~h}$ 後. ミト. 鉄-Hx. Mitochondria. 6 hours after the injection of lauric acid. Iron-hematoxglin.

11. オ酸けレチチン注射の $3 \mathrm{~h}$ 後. ミト. 鉄-Hx. Mitochondria. $3 \mathrm{~h}$. after the injection of the emulsion of oleic acid and lecithin.

12 ' 12 . レチチン注射の $3 \mathrm{~h}$ 後. ミト. 鉄-Hx. Mitochondria. $3 \mathrm{~h}$. after the injection of lecithin. 
石橋悟 (附図 2)

脂肪腹腔内注射

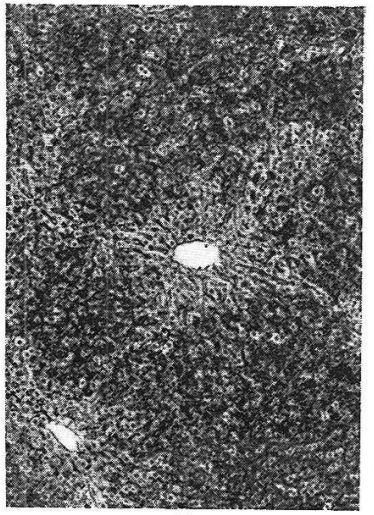

7

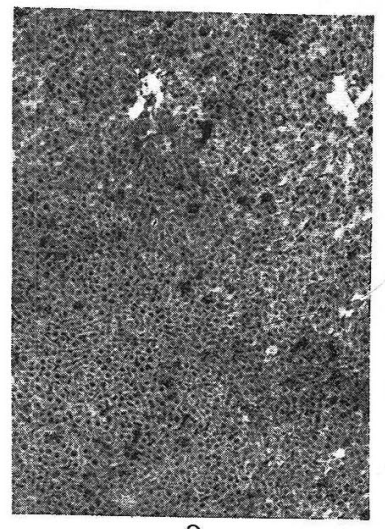

9

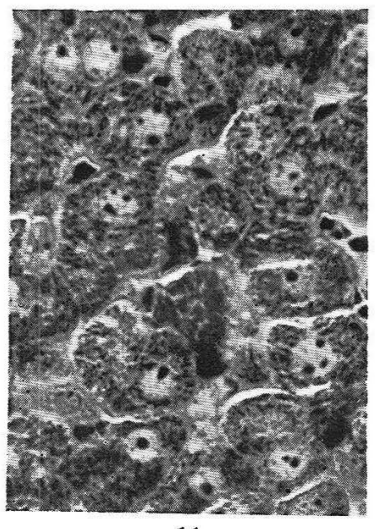

11

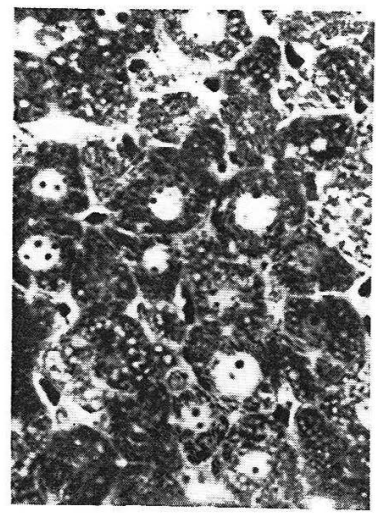

8
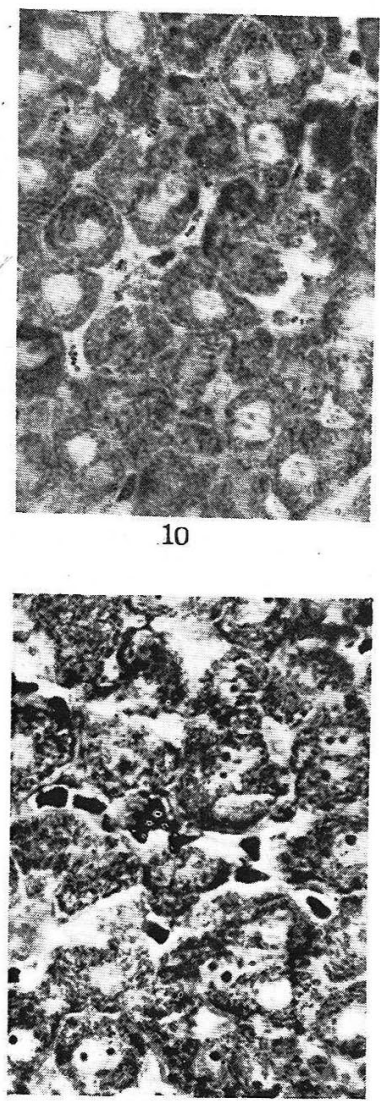

12

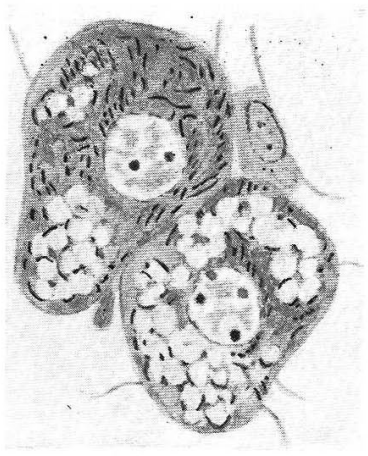

$8^{\prime}$
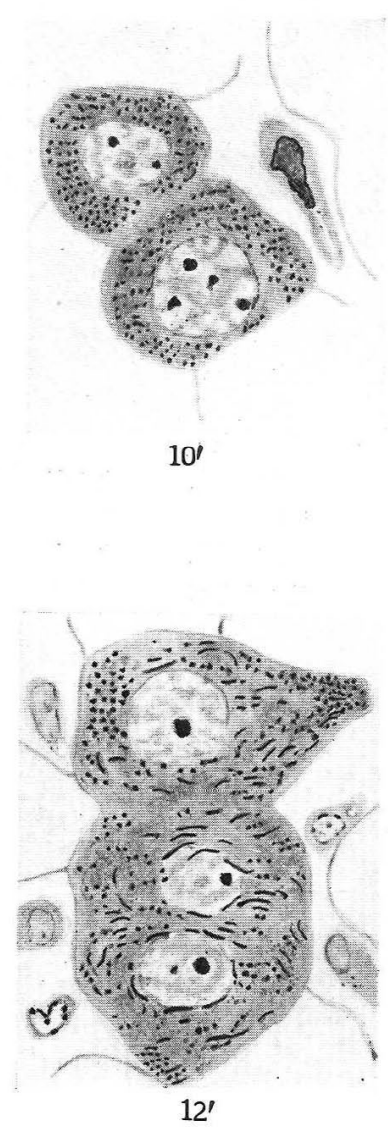


\section{附図 3 .}

閉塞特脂肪腹腔內泩射 Intraperitoneal injection of fatty substances after the blockage of KUPFFER cells.

13. 才酸注射の $1 \mathrm{~h}$ 後. 脂肪 (A群). シャールラッハロート. Fat. 1 hour after the injection of oleic acid (A group of rats). Scarlet red.

14. ラ酸泩射の $1 \mathrm{~h}$ 後. 脂肪 (A 群). シャールラッハロート. Fat. 1 hour after the injection of lauric acid (A group). Scarlet red.

15，15'. 才酸注射の $1 \mathrm{~h}$ 後. ミト (A 群). 鉄-Hx. Mitochondria. 1 hour after the injection of oleic acid (A group). Iron-hematoxylin.

16， 16'. ラ酸注射の $3 \mathrm{~h}$ 後. ミト (A 群). 鉄-Hx. Mitochondria. 3 hours after the injection of lauric acid (A group). Iron-hematoxylin.

17. 才酸泩射の $1 \mathrm{~h}$ 後. 脂肺 (B 群). ズダンブラック. Fat. 1 hour after the injection of oleic acid (B group). Sudan black.

18. 脂肪酸注射前 (対照). ミト (B 群). 鉄-Hx. Mitochondria (for control). (B group). Iron-hematoxylin.

19, 19'. 才酸注射後 $1 \mathrm{~h}$. ミト (B群). 鉄-Hx. Mitochondria. 1 hour after the injection of oleic acid (B group). Iron-hematoxylin.

20,20 '. 才酸注射の $6 \mathrm{~h}$ 後. ミト (B群). 鉄-Hx. Mitochondria. 6 hours after the injection of oleic acid (B group). Iron-hematoxylin. 
石橋悟(附図 3)

閉塞時脂肪注 射

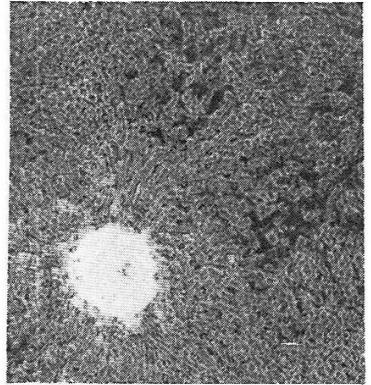

13

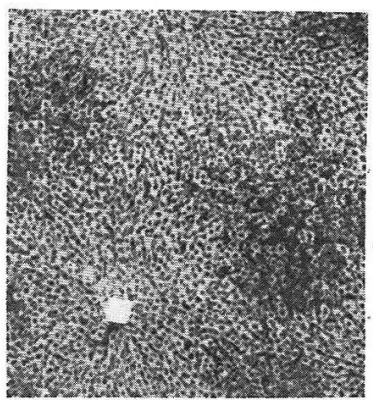

14

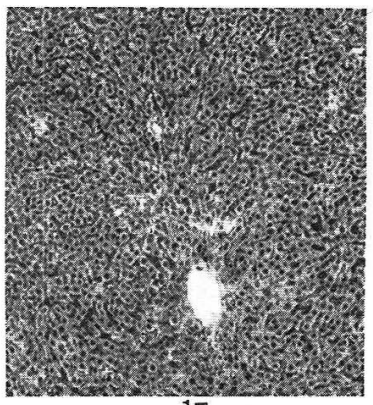

17

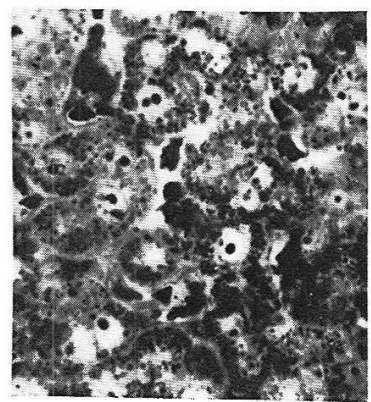

18

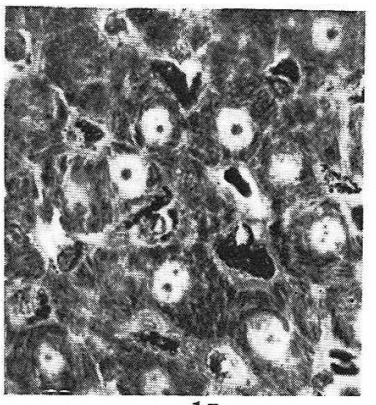
15

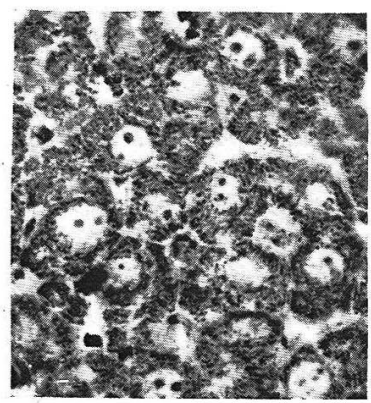

16

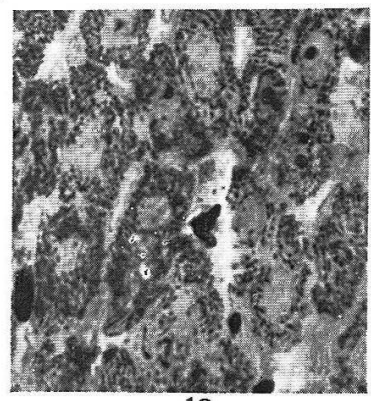

19

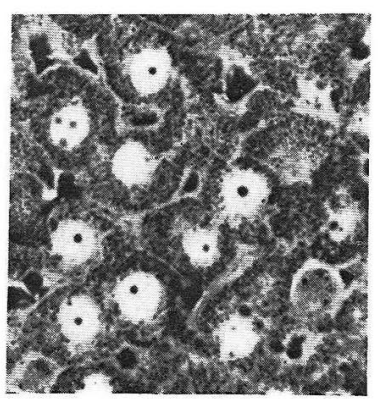

20
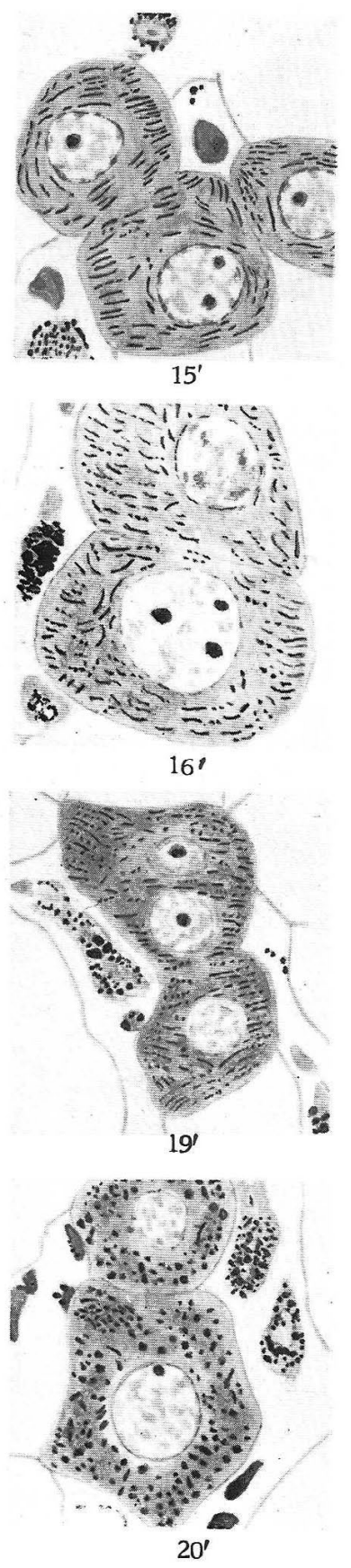
附図 4.

ゼラチン腹腟內泩射後の脂肪酸の腹腟內泩射. Intraperitoneal Injection of fatty acids after the intraperitoneal iniection of gelatin.

21. 才酸注射の $6 \mathrm{~h}$ 後 (I 群). 脂助. シャールラッハロート. Fat. 6 hours after the injection of oleic acid (I. group). Scarlet red.

22. 脂肪酸注射前 (II 群). 脂肪. シャールラッハロート. Fat (for control). (II. group). Scarlet red.

23. 才酸注射の $6 \mathrm{~h}$ 後 (II. 群)。肺肪。シャールラッツロート. Fat. 6 hours af ter the injection of oleic acid (II. group).

$2424^{\prime}$. 才酸注射の $3 \mathrm{~h}$ 後 (I. 群). ミト. 鉄-Hx. Micochondria. 3 hours after the injection of oleic acid (I. group).

$25,25^{\prime}$. 脂肪酸注射前 (II. 群)。 ミト. 鉄-Hx. Mitochondria (for control) (II. group). Iron-hematoxglin.

26, 26'. 才酸注射の $3 \mathrm{~h}$ 後 (II. 群)。ミ卜. 鉄-Hx. Mitochondria. 3 hours after the injection of oleic acid (II. group). Iron-hematoxglin. 
石橋悟(附図 4)

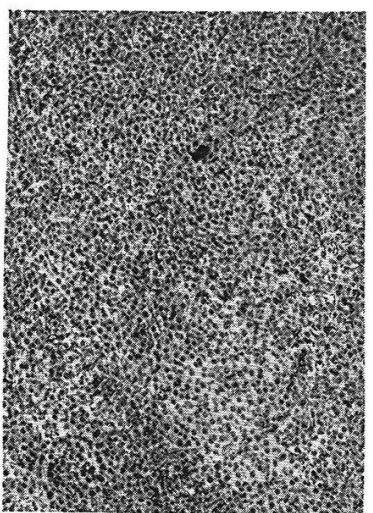

21

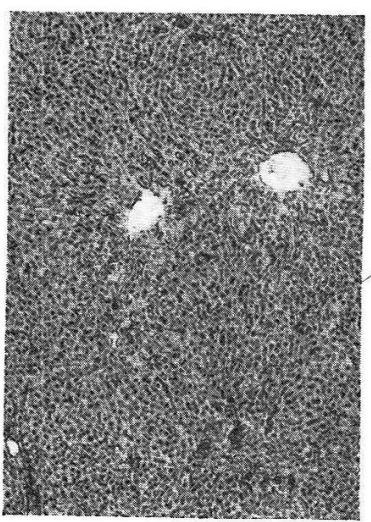

22

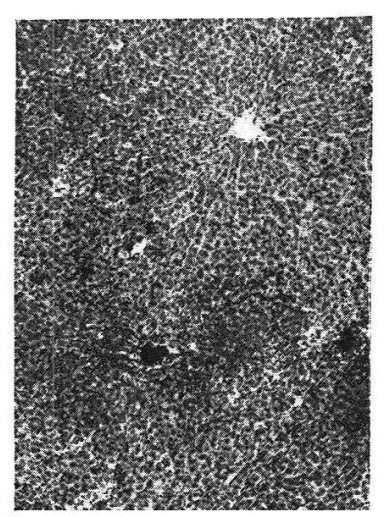

23

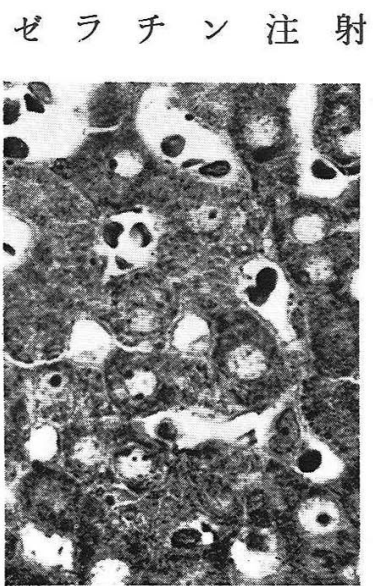

24

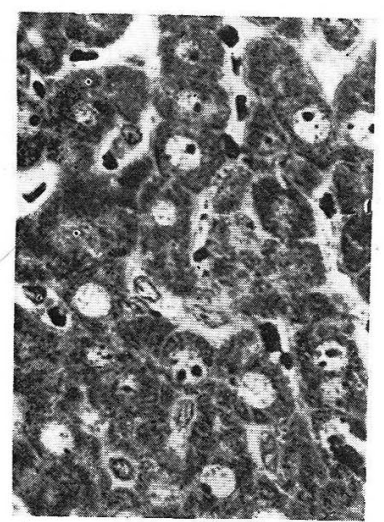

25

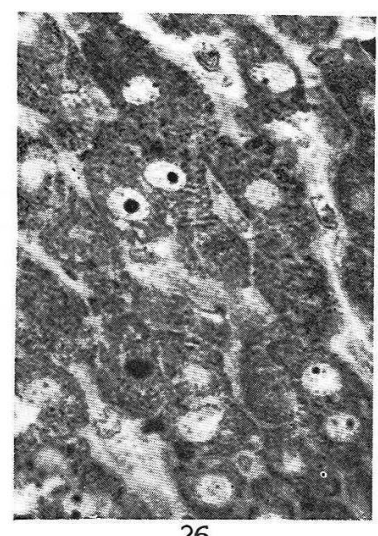

26

557

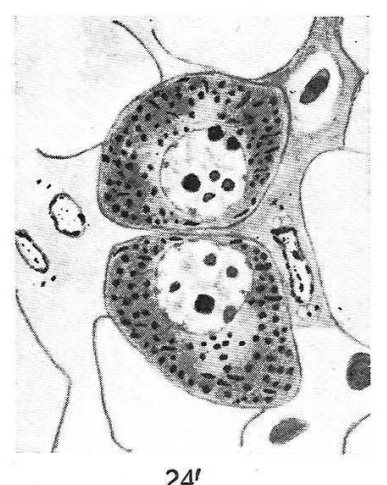

$24^{\prime}$

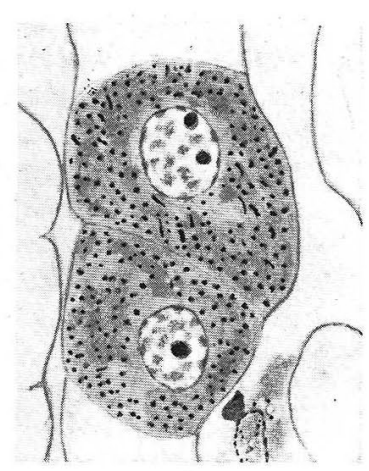

$25^{\prime}$

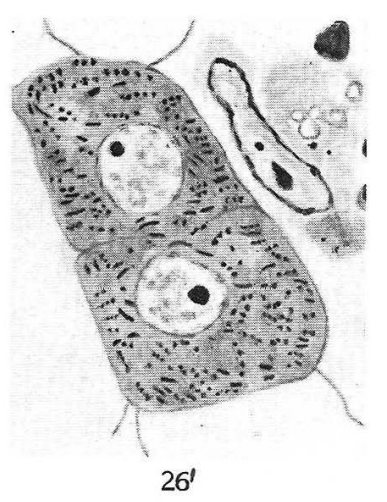


附図 5.

脂肪骀夋の聘內注射 Intrasplenic injection of fatty acids.

27, 27'. 才酸注射の $6 \mathrm{~h}$ 後. ミト. 鉄-Hx. Mitochondria. 6 hours after the injection of oleic acid. Iron-hematoxylin.

28，28'. ラ酸注射の $6 \mathrm{~h}$ 後. ミト. 鉄-Hx. Mitochondria. 6 hours after the injection of lauric acid. Iron-hematoxylin.

29. 才酸注射の $12 \mathrm{~h}$ 後. 門脈周团堌殖. 鉄-Hx. 12 hours after the injection of oleic acid. Periportal growth. Iron-hematoxylin. Intrasplenic injection of fatty acids (continuation).

31. 才酸泩射の $3 \mathrm{~h}$ 後. 肝細肪の変性. 鉄-Hx. 3 hours after the injection of oleic acid. Degeneration of liver cells. Iron-hematoxylin. 
石橋悟（附図 5)

脂肪酸脾内注射

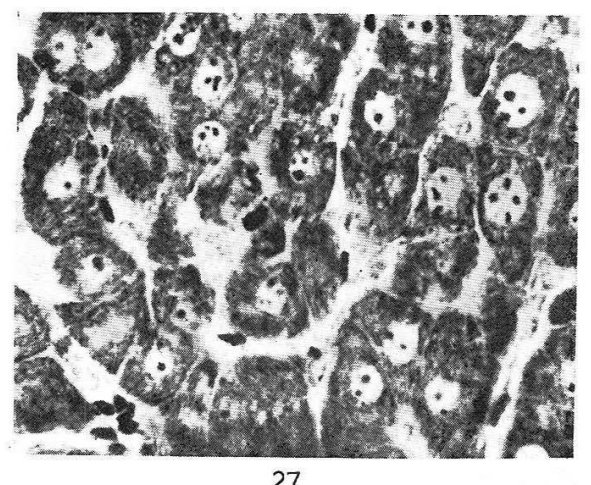

27

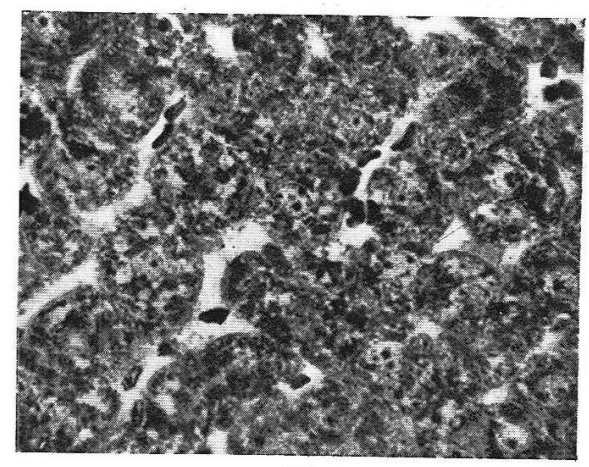

28

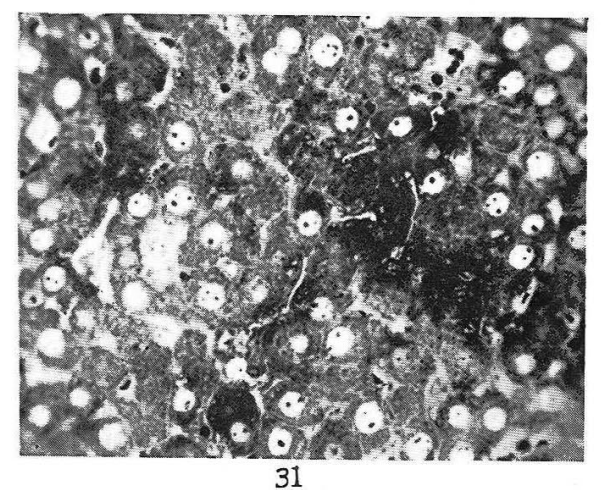

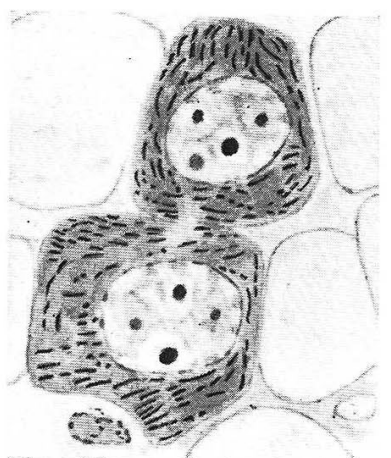

$27^{\prime}$
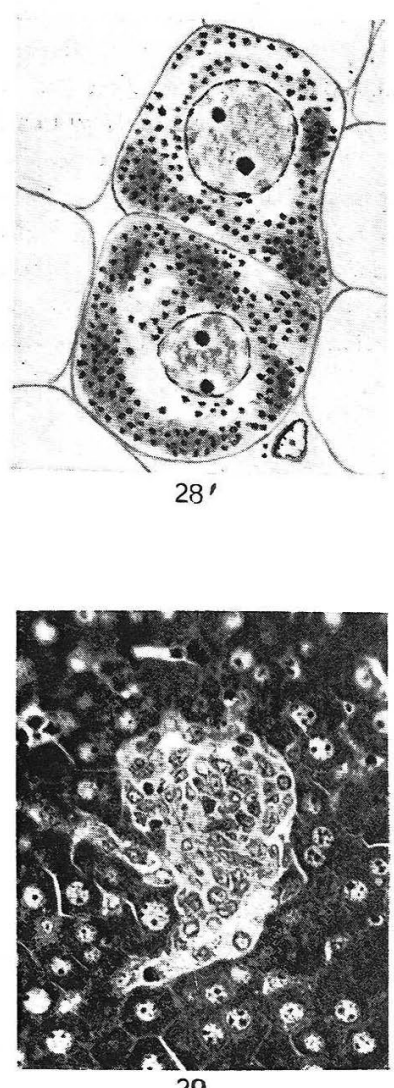

29 
附四 6 .

30. ウ酸注射の $12 \mathrm{~h}$ 後. 組織球等の増加. ジャールラッハロート. 12 hours after the injection of undecyleic acid. Increase of histiocytes etc. Scarlet red.

32. 才酸注射の $24 \mathrm{~h}$ 後. 肝細肪の変性. -シャールラッハロート. 24 hours after the injection of oleic acid. Degeneration of liver cells. Scarlet red.

33， 33'. 才酸注射の $24 \mathrm{~h}$ 後. ミ卜. 肝細肪の恋性. 鉄-Hx. 24 hours after the injection of oleic acid. Degeneration of liver cells. Iron-hematoxylin.

$34,34^{\prime}$. ウ酸洼身の $3 \mathrm{~h}$ 後. ミ1. 肝細肪の変性. 鉄-Hx. 3 hours after the injection of undecyleic acid. Degenertion of liver cells. Iron-hematoxylin.

35. ラ酸洼射の $12 \mathrm{~h}$ 後. 肝細肪の変性. シャールラッハロート. 12 hours after the injection of lauric acid. Degeneration of liver cells. Scarlet red.

36, 36'. 亏酸注射の $12 \mathrm{~h}$ 後. ミト. 肝細肜の変性. 鉄-Hx. 12 hours after the injection of lauric acid. Degeneration of liver cells. Iron-hematoxylin. 
石橋悟 (附図 6)

脂肪酸熷内注射

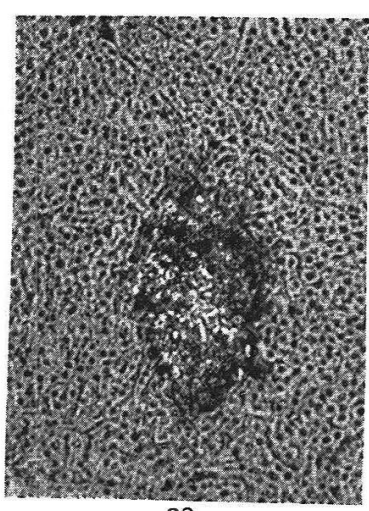

32

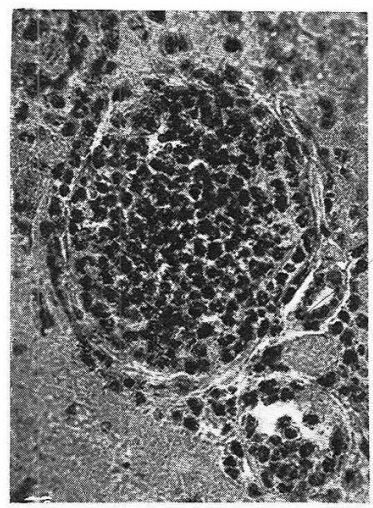

30

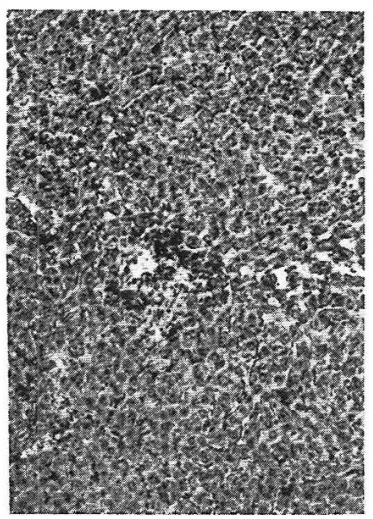

35

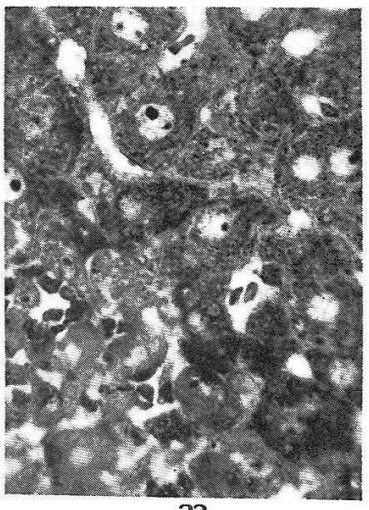

33

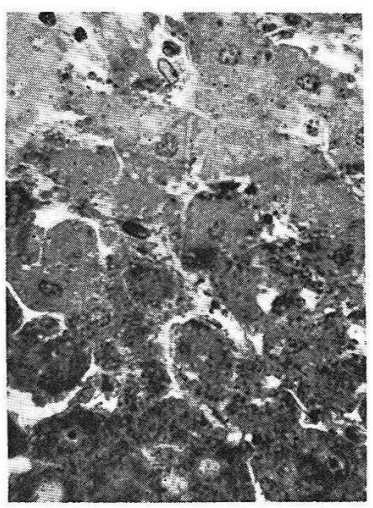

34

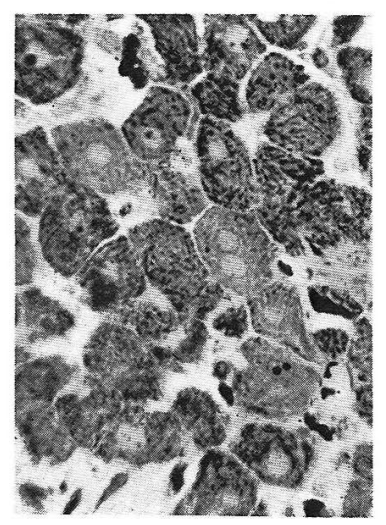

35
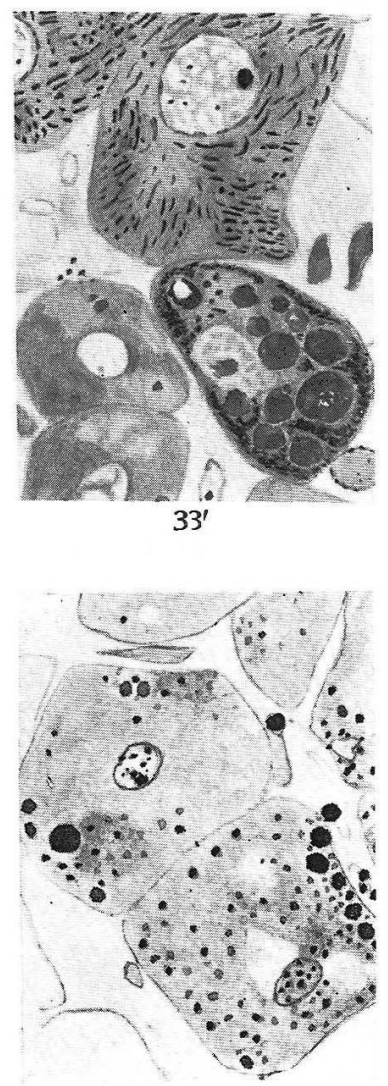

$34^{\prime}$

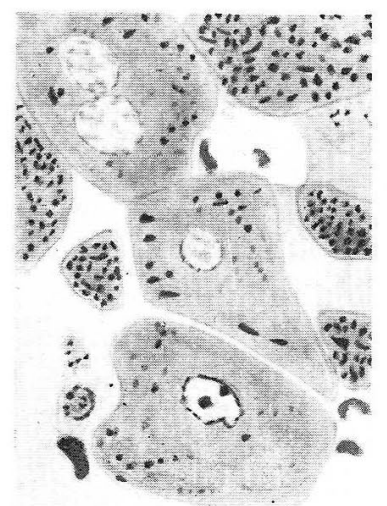

$36^{\prime}$ 